\title{
Design of Self-Supported Flexible Nanostars MFe-LDH@ Carbon Xerogel-Modified Electrode for Methanol Oxidation
}

\author{
Ghada M. Abdelrazek ${ }^{1,2}$, Mohamed M. EL-Deeb ${ }^{3, *(D)}$, Ahmed A. Farghali ${ }^{1}$, Agustín F. Pérez-Cadenas ${ }^{4,5, *(D)}$ \\ and Abdalla Abdelwahab 1,6 (D)
}

1 Materials Science and Nanotechnology Department, Faculty of Postgraduate Studies for Advanced Sciences, Beni-Suef University, Beni-Suef 62511, Egypt; ghadaabdelrazek123@gmail.com (G.M.A.); farghali@psas.bsu.edu.eg (A.A.F.); aabdelwahab@psas.bsu.edu.eg (A.A.)

2 Chemistry Department, Faculty of Engineering, Basic Science, Misr University for Science and Technology (MUST), 6th of October City, Giza 12566, Egypt

3 Applied Electrochemistry Laboratory, Chemistry Department, Faculty of Science, Beni-Suef University, Beni-Suef 62511, Egypt

4 Carbon Materials Research Group, Department of Inorganic Chemistry, Faculty of Sciences, University of Granada, Campus Fuentenueva s/n, 18071 Granada, Spain

5 Unit of Excellence in Chemistry Applied to Biomedicine and the Environment, University of Granada, 18071 Granada, Spain

6 Faculty of Science, Galala University, Sokhna, Suez 43511, Egypt

* Correspondence: mohamedmostafa@science.bsu.edu.eg (M.M.E.-D.); afperez@ugr.es (A.F.P.-C.)

check for updates

Citation: Abdelrazek, G.M.; EL-Deeb, M.M.; Farghali, A.A.; Pérez-Cadenas, A.F.; Abdelwahab, A. Design of Self-Supported Flexible Nanostars MFe-LDH@ Carbon Xerogel-Modified Electrode for Methanol Oxidation. Materials 2021, 14, 5271. https://doi.org/10.3390/ ma14185271

Academic Editor: Enrico Negro

Received: 21 August 2021

Accepted: 10 September 2021

Published: 13 September 2021

Publisher's Note: MDPI stays neutral with regard to jurisdictional claims in published maps and institutional affiliations.

Copyright: (c) 2021 by the authors. Licensee MDPI, Basel, Switzerland. This article is an open access article distributed under the terms and conditions of the Creative Commons Attribution (CC BY) license (https:// creativecommons.org/licenses/by/ $4.0 /)$.

\begin{abstract}
Layered double hydroxides (LDHs) have emerged as promising electrodes materials for the methanol oxidation reaction. Here, we report on the preparation of different LDHs with the hydrothermal process. The effect of the divalent cation (i.e., $\mathrm{Ni}, \mathrm{Co}$, and $\mathrm{Zn}$ ) on the electrochemical performance of methanol oxidation was investigated. Moreover, nanocomposites of LDHs and carbon xerogels (CX) supported on nickel foam (NF) substrate were prepared to investigate the role of carbon xerogel. The results show that NiFe-LDH/CX/NF is an efficient electrocatalyst for methanol oxidation with a current density that reaches $400 \mathrm{~mA} \cdot \mathrm{m}^{-2}$ compared to 250 and $90 \mathrm{~mA} \cdot \mathrm{cm}^{-2}$ for $\mathrm{NiFe}-\mathrm{LDH} / \mathrm{NF}$ and NF, respectively. In addition, all LDH/CX/NF nanocomposites show excellent stability for methanol oxidation. A clear relationship is observed between the electrodes crystallite size and their activity to methanol oxidation. The smaller the crystallite size, the higher the current density delivered. Additionally, the presence of carbon xerogel in the nanocomposites offer 3D interconnected micro/mesopores, which facilitate both mass and electron transport.
\end{abstract}

Keywords: fuel cells; particle size; methanol oxidation; carbon xerogel

\section{Introduction}

The fast consumption of fossil fuels and constantly growing environmental issues have promoted major research interests in developing clean, reliable, and sustainable technologies for energy conversion, such as fuel cells [1,2]. From this point of view, direct methanol fuel cells (DMFC) have attracted considerable attention for mobile and stationary electronic devices because of the high energy density of methanol, low operating temperature, high performance, low cost, easy storage, and low pollutant emissions [3,4]. Because of the possible uses of lower-cost non-platinum catalysts to achieve higher methanol oxidation, alkaline DMFCs are considered more interesting than acidic ones due to the less corrosive alkaline environment that improves their durability [5]. Methanol is preferable to ethanol as a fuel due to its high energy density, easy storage, preparation, and availability [6]. Currently, the two most significant technological barriers to DMFCs development are the low catalytic activity of anode (sluggish anode reaction) [7] and "methanol cross-over" to the cathode [8]. The latter problem emerges from the fact that methanol diffuses through the electrolytes and interacts directly with oxygen at the cathode, greatly reducing the 
efficiency of the used methanol and losing power of the fuel cell [9]. A variety of noble metals have been used as catalysts for electrocatalytic methanol oxidation, such as $\mathrm{Pt}$ and Pt-based alloys $[10,11]$. However, they suffer from high cost, low reserves, and extreme poisoning by the intermediates, such as $\mathrm{CO}_{2}$ [12]. Thus, current research has been aimed at developing new low-cost and highly-active catalyst materials for methanol oxidation reaction (MOR) [13]. The literature offers an overview of catalysts for DMFCs such as metal oxide [14], carbon nanotubes as a support material [15,16], metal organic framework and their composites [17]. Nanomaterials are interesting in the electrochemical field owing to their high surface area, unique structure, and highly promising physicochemical properties. Among a range of hydroxides and oxides, layered double hydroxides (LDHs) are a class of two-dimensional (2D) anionic clays made up of positively charged brucite-like host layers and interlayer anions of exchangeable charge balancing to obtain electro-neutrality [18-21]. Their general formula: $\left[\mathrm{M}^{\mathrm{II}}{ }_{1-\mathrm{x}} \mathrm{M}^{\mathrm{III}}{ }_{\mathrm{x}}(\mathrm{OH})_{2}\right]^{\mathrm{x}}\left[\mathrm{A}^{\mathrm{n}-}\right]_{\mathrm{x} / \mathrm{n}} \cdot \mathrm{yH}_{2} \mathrm{O}$, where $\mathrm{M}^{\mathrm{II}}$ and $\mathrm{M}^{\mathrm{III}}$ are arranged in the LDHs layers as divalent and trivalent metal cations, $\mathrm{A}^{\mathrm{n}-}$ is an $\mathrm{n}$-valent anion, and $y$ is the number of water molecules in the interlayer [22]. Recently, due to their possible technical applications in areas such as separation, catalysis, sensors, and electrochemistry, these layered materials have recently received considerable attention due to desirable properties, including well anion exchange, high surface area, and low cost $[23,24]$. These attractive features enhance more exposed active sites and mass or ion transport, which are useful for improving the electrocatalytic activity, which clearly drives them as alternative materials to catalyze the oxidation of methanol. In addition, the development of surface porosity in nanosheets enhances the diffusion of ionic reagents, and the rise of unsaturated coordination sites can be accomplished [25].

Unfortunately, LDH aggregation and low electrical conductivity decreases its stability and suppresses its electrochemical activity [26]. Consequently, a combination of LDH with conductive support can reduce the agglomeration of LDH and promote its electrocatalytic activity [27]. Several studies found a relationship between the material particle size and its activity in a certain electrochemical application [28-30]. In this context, it is important to decrease the composite particle size for better electrochemical performance [31]. For example, Chae, Gyu S. et al. [30] prepared nanostructured FeS dispersed onto N, S dualdoped carbon nanotube-graphene composite support as electrocatalyst for the oxygen reduction reaction. In this study, a synergy effect between the composite particle size and its activity was observed, i.e., the lower the particle size, the higher the produced activity.

Therefore, combining LDH with conductive substrate materials, such as carbon materials, can effectively overcome these problems. The support materials include graphene, carbon nanotube, carbon quantum dots, and carbon xerogel (CX). Carbon xerogel is a novel nanostructured carbon material that has excellent properties of high specific surface area, high porosity, controllable pore size, high density, and high conductivity [32,33]. It can be obtained in different forms, and its structure can be controlled according to the synthesis and processing conditions. Therefore, $\mathrm{CX}$ was used as a support material in various applications such as catalysis [34], electro-catalysis [35], adsorption [36], and energy storage [37]. Wang et al. [21] reported that NiAl-LDH/AuNPs/GCE displays a higher catalytic activity for methanol oxidation. Compared to NiAl-LDH without AuNP, the reinforcement can be related to the synergistic effect between them. Furthermore, according to [38], hierarchical flower catalysts $\mathrm{Au} / \mathrm{NiAl}-\mathrm{LDH}$ were prepared for the selectivity of alcohols oxidation, and it was observed that the hierarchical pores showed activity greater than the common $\mathrm{Au} / \mathrm{NiAl}-\mathrm{LDH}$, which attributed to the shape selectivity of macropores.

$\mathrm{Li}$ et al. [39] demonstrated that hierarchical nanoarrays of MFe-LDH, i.e., $\mathrm{M}=\mathrm{Ni}, \mathrm{Co}$, and $\mathrm{Li}$, show highly electrocatalytic performance towards different oxidation reactions of small molecules, i.e., water, hydrazine, methanol, and ethanol. The resulting arrays of $\mathrm{NiFe}-\mathrm{LDH}$ show promising behavior in the oxygen evolution reaction (OER).

Vlamidis et al. [18] demonstrated that NiFe-LDHs can achieve high activity for the oxidation of methanol as a consequence of the role played by Fe in the electrocatalytic process. 
Additionally, Jia et al. [13] synthesized $\mathrm{NiFe} / \mathrm{LDH}$ and $\mathrm{NiFe} / \mathrm{LDH} @ \mathrm{MnO}_{2}$ nanosheets for ethanol oxidation. The $\mathrm{LDH} @ \mathrm{MnO}_{2}$ showed excellent catalytic activity for oxidation of ethanol compared to NiFe. The enhancement could be attributed to $\mathrm{MnO}_{2}$, which increases the concentration of OH ads-species on the surface of Ni-Fe LDH. Gamil et al. [40] prepared NiCr-LDH@rGO nanocomposite with different concentrations of reduced graphene oxide, which showed much higher activity for the electro-oxidation of methanol than pure $\mathrm{NiCr}-$ LDH. Eldeeb et al. [35] fabricated nickel cobaltite/CX nanocomposite by hydrothermal method. The data showed that the $\mathrm{NiCo}_{2} \mathrm{O}_{4} / \mathrm{CX}$ provides higher catalytic activity compared to pure $\mathrm{NiCo}_{2} \mathrm{O}_{4}$, which is attributed to the synergistic effect of the pore geometry. Nickel Foam (NF) is an attractive current collector commonly used in energy storage and energy conversion devices due to the good electrocatalytic activity of $\mathrm{Ni}$ and the properties such as the high surface area, high porosity that promotes the mass transfer of the reactants, excellent mechanical strength, electrical conductivity, and resistance of corrosion [41].

Direct deposition of active material on the NF facilitates contact between the electrode material and the current collector, which improves ion transport and electrochemical performance [42]. Yu et al. [43] reported greater electro-oxidation of methanol and stability of mesoporous $\mathrm{NiCo}_{2} \mathrm{O}_{4}$ nanorods with graphene on nickel foam by a chemical vapor deposition method. Roy et al. [44] prepared cobalt hydroxide $\mathrm{Co}(\mathrm{OH})_{2}$ nanoflakes on $\mathrm{Ni}$ foam by an electroplating technique. The results showed that $\mathrm{Co}(\mathrm{OH})_{2}$ has excellent electrocatalytic activity towards methanol oxidation, and this activity is attributed to the direct growth of an electroactive nanostructure which improves mechanical adhesion and facilitates the transfer of electrons between the current collector and the electrocatalyst.

The current challenge with methanol electro-oxidation is to develop promising inexpensive electrode materials with excellent efficiency. The nanocomposites of Layered double hydroxides and carbon xerogels have not been studied before as electrocatalysts for methanol electro-oxidation. Therefore, in this work, six nanohybrids composites of Layered double hydroxides supported on nickel foam were prepared by the hydrothermal process with and without carbon xerogels to investigate the role of carbon xerogel on the electrode activity. Moreover, the effect of the divalent cation on the electrochemical activity of methanol oxidation was studied by using three divalent cations, i.e., $\mathrm{M}^{\mathrm{II}}=\mathrm{Ni}$, $\mathrm{Co}$, and $\mathrm{Zn}$, while the used trivalent cation Fe was fixed. The prepared nanocomposites were denoted as NiFe-LDH/NF, NiFe-LDH/CX/NF, CoFe-LDH/NF, CoFe-LDH/CX/NF, $\mathrm{ZnFe}-\mathrm{LDH} / \mathrm{NF}$, and ZnFe-LDH/CX/NF.

\section{Materials and Methods}

\subsection{Materials}

Nickel nitrate $\mathrm{Ni}\left(\mathrm{NO}_{3}\right)_{2} \cdot 6 \mathrm{H}_{2} \mathrm{O}$, iron nitrate $\mathrm{Fe}\left(\mathrm{NO}_{3}\right)_{3} \cdot 9 \mathrm{H}_{2} \mathrm{O}$, cobalt nitrate $\mathrm{Co}\left(\mathrm{NO}_{3}\right)_{2}$. $6 \mathrm{H}_{2} \mathrm{O}$, zinc nitrate $\mathrm{Zn}\left(\mathrm{NO}_{3}\right)_{2} \cdot 6 \mathrm{H}_{2} \mathrm{O}$, nickel acetate $\left(\mathrm{Ni}(\mathrm{Ac})_{2} \cdot 6 \mathrm{H}_{2} \mathrm{O}\right.$, urea, resorcinol, and formaldehyde were all used without further purification. Deionized (DI) water was used for synthesis and treatment processes under ambient conditions. Ni foam was used as a substrate and current collector. It was sonicated using $1 \mathrm{M} \mathrm{HCl}$ solution followed by acetone, ethanol, and distilled water for $10 \mathrm{~min}$ each in sequence to remove the oxide layer. The supporting electrolyte for all electrochemical experiments was $1 \mathrm{M} \mathrm{KOH}$.

\subsection{Preparation of Carbon Xerogels (CX)}

CX is prepared by sol-gel as previously reported [34]. In short, resorcinol (R) and formaldehyde (F) were dissolved in water $(\mathrm{W})$ in the presence of nickel acetate instead of alkaline catalyst to improve the resulting surface area. The weight of the metal catalyst was calculated to be $6 \mathrm{wt} . \%$ of the produced CX. The molar ratios used for R/F and $\mathrm{R} / \mathrm{W}$ were 0.5 and 0.06 , respectively. After preparing the initial mixture, the mixture was subjected to stirring, then poured into glass molds. The curing and gelation temperature was $40^{\circ} \mathrm{C}$ for one day, then $80^{\circ} \mathrm{C}$ for five days. The organic gels produced were subjected to microwave drying to obtain their corresponding organic xerogels. Finally, CX was obtained 
by carbonizing organic xerogels at $900{ }^{\circ} \mathrm{C}$ for $2 \mathrm{~h}$ with a heating rate of $5{ }^{\circ} \mathrm{C} / \mathrm{min}$ in the presence of $\mathrm{N}_{2}$ gas.

\subsection{Preparation of Ni-Fe LDH Nanosheet Array on NF Substrate}

Nickel-iron layered double hydroxide (NiFe-LDH) nanosheet array on $\mathrm{Ni}$ foam was synthesized via a simple hydrothermal process [45]. Typically, $\mathrm{Ni}\left(\mathrm{NO}_{3}\right)_{2} \cdot 6 \mathrm{H}_{2} \mathrm{O}(0.345 \mathrm{~g})$, $\mathrm{Fe}\left(\mathrm{NO}_{3}\right)_{3} \cdot 6 \mathrm{H}_{2} \mathrm{O}(0.159 \mathrm{~g})$, and urea $(0.166 \mathrm{~g})$ were dissolved in $160 \mathrm{~mL}$ of deionized water. The mixture was stirred at room temperature for $15 \mathrm{~min}$ to form a clear solution and then transferred to a $200 \mathrm{~mL}$ stainless steel Teflon autoclave. A pretreated piece of NF was dipped into the reaction solution. The autoclave was tightly closed and kept at $100{ }^{\circ} \mathrm{C}$ for $24 \mathrm{~h}$ in an electronic oven. After naturally cooling to room temperature, the coated NF was washed several times with distilled water and absolute ethanol. For comparison, $\mathrm{CoFe}-\mathrm{LDH}$ and $\mathrm{ZnFe}-\mathrm{LDH} / \mathrm{Ni}$ foam nanosheet arrays were synthesized with the same procedure.

\subsection{Preparation of Ni-Fe LDH Nanosheet Array/CX on NF Substrate}

An amount of $40 \mathrm{mg}$ of $\mathrm{CX}$ was dispersed in $30 \mathrm{~mL}$ of ethanol using an ultrasonic probe (SONICS, Probe diameter 5-8 mm, pulse, on/ off 9.9 and $3 \mathrm{~s}$, Newtown, CT, USA) for $15 \mathrm{~min}$. Then, a solution containing $\mathrm{Ni}\left(\mathrm{NO}_{3}\right)_{2} \cdot 6 \mathrm{H}_{2} \mathrm{O}(0.345 \mathrm{~g}), \mathrm{Fe}\left(\mathrm{NO}_{3}\right)_{3} \cdot 6 \mathrm{H}_{2} \mathrm{O}(0.159 \mathrm{~g})$, and urea $(0.166 \mathrm{~g})$ in $130 \mathrm{~mL}$ of $\mathrm{H}_{2} \mathrm{O}$ was added and ultrasonicated for $15 \mathrm{~min}$. A piece of the pretreated Ni foam $(1 \mathrm{~cm} \times 5.5 \mathrm{~cm})$ was then immersed in a $200 \mathrm{~mL}$ Teflon-lined autoclave containing the above mixture solution. The autoclave was sealed, kept at $100{ }^{\circ} \mathrm{C}$ for $24 \mathrm{~h}$, and then allowed to cool naturally to room temperature after being washed several times with distilled water and ethanol and dried at $60^{\circ} \mathrm{C}$ for $6 \mathrm{~h}$. Co-Fe LDH/CX/NF and $\mathrm{Zn}-\mathrm{Fe} \mathrm{LDH} / \mathrm{CX} / \mathrm{NF}$ were synthesized with the same procedure.

\subsection{Characterization}

The structures of the prepared materials were examined using a transmission electron microscope HRTEM (JEOL JEM 2100, JEOL, Tokyo, Japan), and morphologies were checked using the scanning electron microscope SEM (FEI-Quanta FEG-250 SEM, Basel, Switzerland). The phase identification and crystallinity were analyzed using X-ray diffraction (PANalytical Empyrean, Eindhoven, Netherlands) with CuKa radiation (wavelength $1.54045 \AA$ )), accelerating voltage of $40 \mathrm{KV}$ and a current of $35 \mathrm{~mA}$. Fourier transformation infrared spectroscopy (FTIR) was performed to obtain information about the intercalation of LDH using Vertex 70 (Bruker, Berlin, Germany). Raman spectroscopy (FT-Raman) of the as-prepared composites was obtained with Bruker Senterra Raman Microscope (Bruker Optics Inc., Germany). The BET surface area and pore size distribution were determined using a surface area analyzer (TriStar II 3020, Micromeritics, Norcross, GA, USA).

\subsection{Electrochemical Measurements}

Electrochemical measurements were carried out using NOVA 1.11 software Potentiostat/Galvanostat (AUTOLAB PGSTAT 302N, Metrohm, Herisau, Switzerland) in a three-compartment glass cell with electroplated film on nickel foam as working electrode, $\mathrm{Pt}$ as counter electrode, and $\mathrm{Ag} / \mathrm{AgCl}$ as reference electrode at room temperature. An aqueous solution of $1 \mathrm{M}$ of $\mathrm{KOH}$ with and without $0.5 \mathrm{M}$ of methanol was used as the electrolyte to study the electrocatalytic activity of the prepared electrodes. The cyclic voltammetry $(\mathrm{CV})$ measurements for each electrode were performed at different scan rates within the potential range of $0-0.7 \mathrm{~V}$. Chronoamperometry (CA) tests were performed at $0.7 \mathrm{~V}$ for $3600 \mathrm{~s}$. Furthermore, the electrochemical impedance spectroscopy (EIS) spectra were taken in the frequency range from $100 \mathrm{kHz}$ to $0.01 \mathrm{~Hz}$. 


\section{Results and Discussions}

\subsection{Physicochemical Properties}

Powder X-ray diffraction (XRD) was conducted to confirm the structure of the synthesized materials. The XRD pattern of the prepared LDHs with different divalent cations is presented in Figure 1a. The reflection peaks of the layered double hydroxide structure are clearly seen. The diffraction peaks at $2 \theta$ of $11.6^{\circ}, 23.2^{\circ}, 34.5^{\circ}, 39.1^{\circ}, 46.5^{\circ}, 59.9^{\circ}$, and $60.9^{\circ}$ could be assigned to the (003), (006), (012), (009), (015), (018), (110), and (113) plane reflections, respectively. The prepared LDHs possess a Rhombohedral crystal system with a space group of R-3 (ICDD card no. 01-082-8040) [46,47]. Figure 1b shows the XRD pattern of the carbon xerogel, which has a diffraction peak at $2 \theta$ of $26^{\circ}$ representing the (002) diffraction plane of graphite, and the two main peaks at $2 \theta$ of $44^{\circ}$ and $51^{\circ}$ are assigned for the metallic nickel that has been used as a catalyst during its preparation. It should be noted that the diffraction peak of amorphous CX at $2 \theta$ of $26^{\circ}$ overlaps with the (006) diffraction plane peak of NiFe-LDH, so it is difficult to be distinguished in the composites. The increase in the graphitic order induces an increase in the nanocomposites crystallinity, which enhances their conductivities; this behavior is clearly seen for NiFe-LDH/CX with the presence of a diffraction peak centered at $2 \theta$ of $26^{\circ}$ [48]. Table 1 represents the average crystallite sizes for the prepared nanocomposites calculated using Scherrer's equation. The increase in the crystallite size is considered evidence for the intercalation of carbon xerogel between the LDH layers. It is apparent that the crystallite size of NiFe-LDF is the least when compared with CoFe-LDF or ZnFe-LDF. Additionally, its composite with carbon xerogel NiFe-LDH/CX has the least crystallite size than CoFe-LDH/CX or ZnFe-LDH/CX. Many publications found a relation between the crystallite size and the activity of the composites for certain applications $[49,50]$.
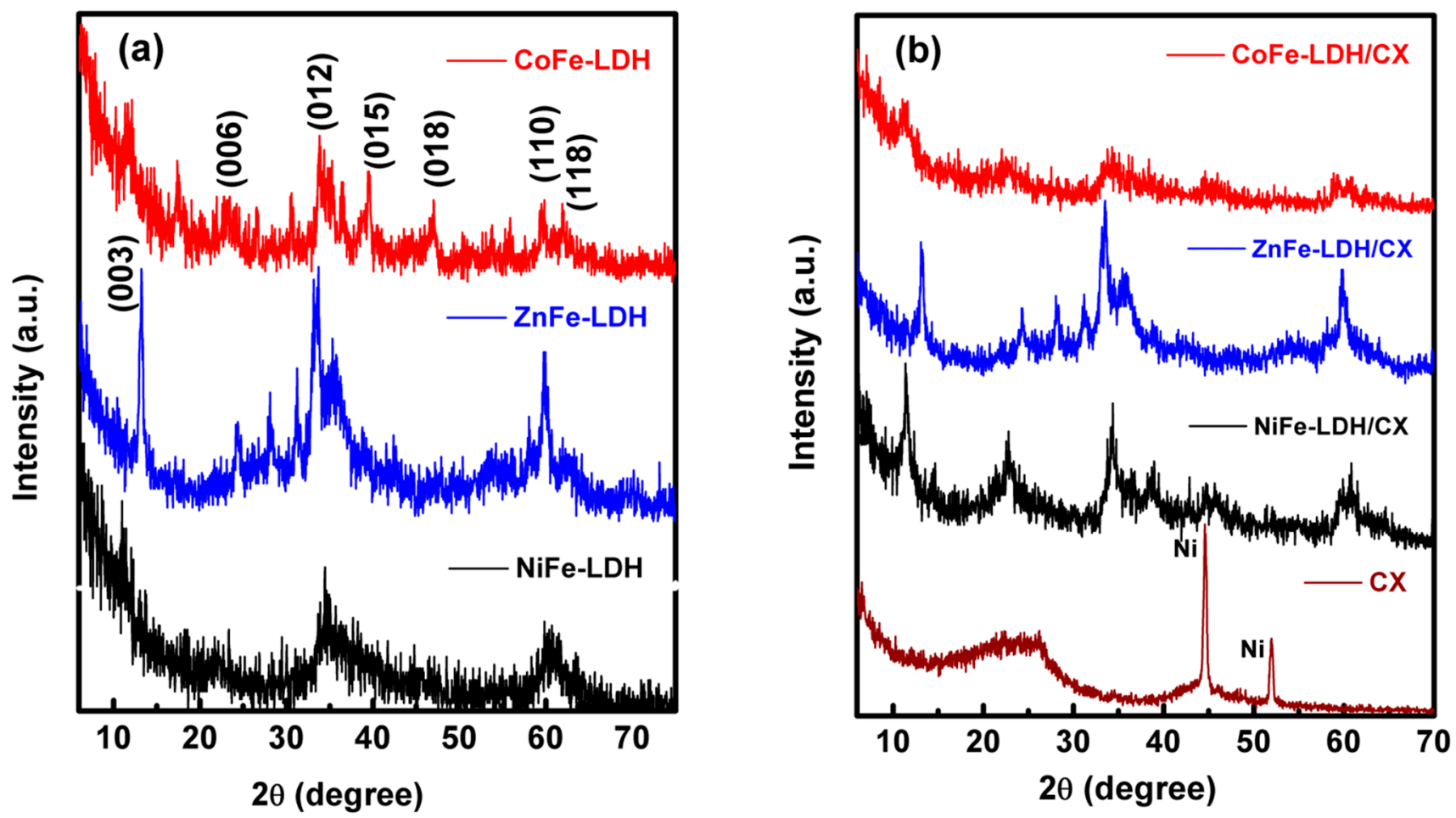

Figure 1. The XRD patterns of (a) XFe-LDH/NF and (b) XFe-LDH/CX/NF. 
Table 1. Crystallite size of the synthesized LDHs.

\begin{tabular}{lc}
\hline Sample Name & The Average Crystallite Size (nm) \\
\hline NiFe-LDH & 15.9 \\
CoFe-LDH & 17.3 \\
ZnFe-LDH & 18.7 \\
NiFe-LDH/CX & 16.9 \\
CoFe-LDH/CX & 23.4 \\
ZnFe-LDH/CX & 26.6 \\
\hline
\end{tabular}

The scanning electron microscopy (SEM) images of the nanocomposites are presented in Figure 2. It is apparent that different morphologies were observed for the prepared LDHs with different divalent cations. In Figure 2a, in addition to the presence of ZnFe-LDH in the layered structure, other two morphologies were observed, namely, nanobundles and nanoflowers with a three-dimensional hierarchical structure, which is also confirmed with TEM, Figure 3a. This morphology was maintained with the incorporation of carbon xerogel in $\mathrm{ZnFe-LDH}$, i.e., $\mathrm{ZnFe-LDH/CX}$, Figures $2 \mathrm{~b}$ and $3 b$, in which the $\mathrm{CX}$ particles are anchored on the ZnFe-LDH flowers and filled the interstitial space of the flowers.

The SEM image for CoFe-LDH, Figure 2c, shows that the LDH has a nanorod structure that has stacked to each other to form sheets and bundles, as also confirmed by TEM Figure 3c, which is in agreement with [51]. With the incorporation of CX into the CoFe$\mathrm{LDH}$, Figures $2 \mathrm{~d}$ and $3 \mathrm{~d}$, the CX is intercalated between the LDH layers, and the CX has been successfully coated on the surface of CoFe-LDH where the nanorod structures can still be observed. It is also clearly shown in Figure 2e that the NiFe-LDH has a continuous structure of interconnected particles, and a proprietary plate-like morphology can be obtained. TEM micrograph for NiFe-LDH, Figure 3e, shows that the morphology of the prepared NiFe-LDH is similar to a plate and uniform structure in nature [47]. Moreover, the combination between NiFe-LDH and CX improved the structure and formed a new morphology, Figures 2 and 3f, SEM and TEM images which show a nanostar structure for $\mathrm{NiFe}-\mathrm{LDH} / \mathrm{CX}$. Figure $2 \mathrm{~g}-\mathrm{h}$ shows the SEM image for the deposition of NiFe-LDH/CX onto the surface of nickel foam; $\mathrm{NiFe}-\mathrm{LDH} / \mathrm{CX} / \mathrm{NF}$, the intrinsic 3D structure of the $\mathrm{Ni}$ foam was well maintained and uniformly covered by NiFe-LDH/CX nanoparticles. For most of these particles, many branches have been developed to give them a star shape. This type of branched particles presumably results from the overgrowth of the initially formed faceted particles. Li et al. suggest a relationship between the materials morphology and their electrochemical activity for methanol electro-oxidation [52].

The chemical composition and main functional groups of nanohybrids were studied by FTIR in the region of $400-4000 \mathrm{~cm}^{-1}$, as observed in Figure $4 \mathrm{a}$. The wide band that appeared at $3420 \mathrm{~cm}^{-1}$ is related to the $\mathrm{OH}$-stretching band of the metal hydroxyl groups and the hydrogen-bonded interlayer of the water molecules [22]. Additionally, the band at 1630 is attributed to the bending mode of the $\mathrm{OH}$ group of water molecules [40]. The peak located at $1380 \mathrm{~cm}^{-1}$ is assigned to the stretching vibrations of $\mathrm{N}-\mathrm{O}$ of $\mathrm{NO}_{3}{ }^{-}$groups, confirming the intercalation of $\mathrm{NO}_{3}{ }^{-}$anions [53]. The peak at $1049 \mathrm{~cm}^{-1}$ corresponds to the stretching vibration of $\mathrm{C}-\mathrm{O}$ [54]. The characteristic bands at 673 is related to metal-OH bending (Hou et al. 2018a; Jin et al. 2016) [55], confirming the existence of the LDH in the composites. 

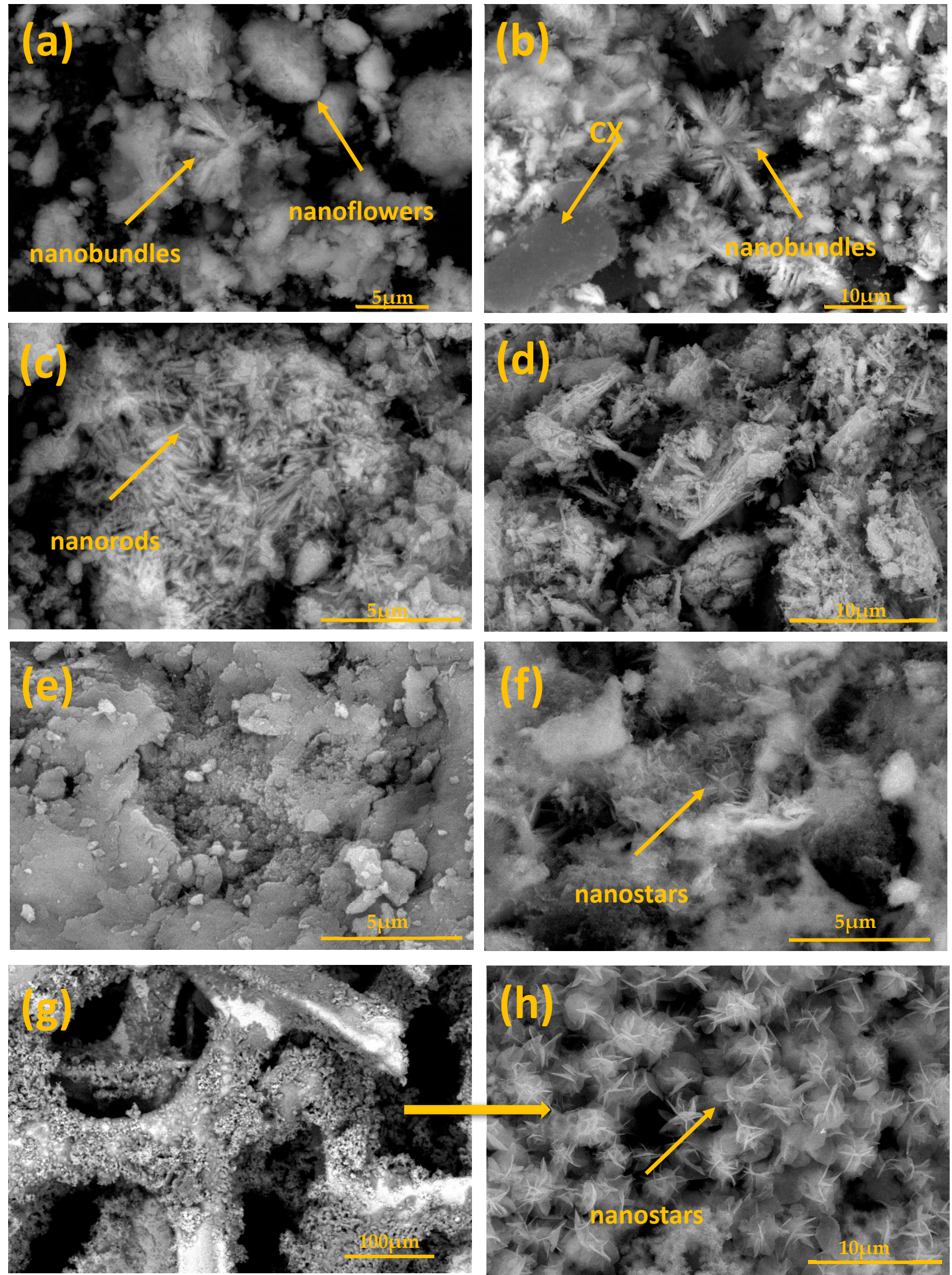

Figure 2. SEM images of (a) ZnFe-LDH, (b) ZnFe-LDH/CX, (c) CoFe-LDH, (d) CoFe-LDH/CX, (e) NiFe-LDH, (f) NiFe$\mathrm{LDH} / \mathrm{CX}$, and (g,h) NiFe-LDH/CX/NF. 

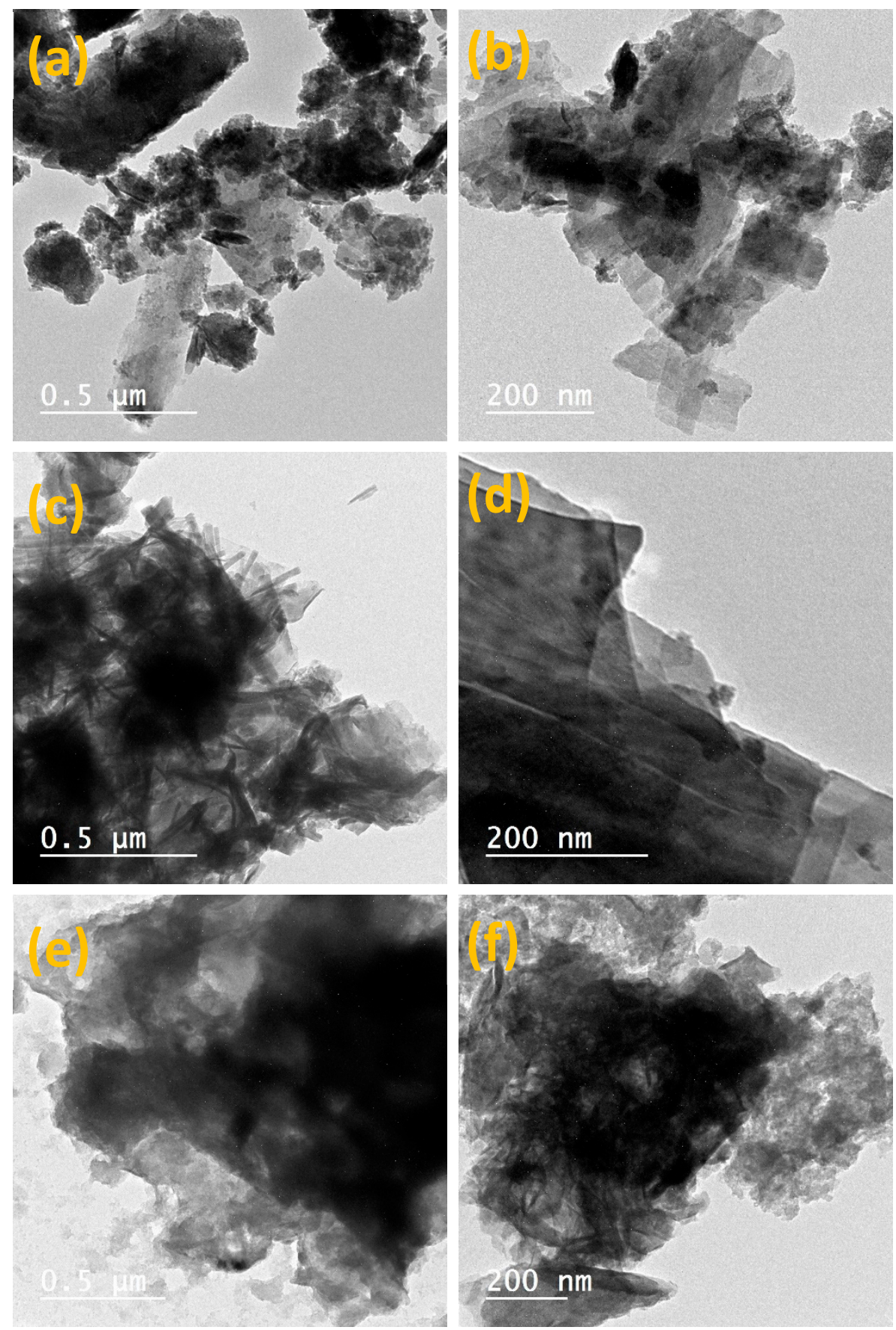

Figure 3. HR-TEM images of (a) ZnFe-LDH, (b) ZnFe-LDH/CX, (c) CoFe-LDH, (d) CoFe-LDH/CX, (e) NiFe-LDH, and (f) $\mathrm{NiFe}-\mathrm{LDH} / \mathrm{CX}$.

In Raman spectra for the prepared LDHs/CX, Figure $4 b$, there are two strong peaks at about 1338 and $1595 \mathrm{~cm}^{-1}$, which could be assigned to the D and $\mathrm{G}$ bands of carbon, respectively [56]. These data confirm the coexistence of LDHs and carbon xerogel in the composites. The $\mathrm{D}$ band is associated with the alternating ring vibrations in condensed benzene rings, while the $\mathrm{G}$ band is associated with the development of the $\mathrm{sp}^{2}$ carbon structure during the carbanization process [34]. The ratio of the intensity of $\mathrm{I}_{\mathrm{D}} / \mathrm{I}_{\mathrm{G}}$ was calculated for the LDHs/CX, Figure $4 \mathrm{~b}$. As it can be seen, the ratio between $\mathrm{I}_{\mathrm{D}} / \mathrm{I}_{\mathrm{G}}$ for $\mathrm{NiFe}-\mathrm{LDH} / \mathrm{CX}$ is the highest one compared to the other two samples, indicating a more disordered structure due to the reduction of the $\mathrm{sp}^{2}$ region size. 

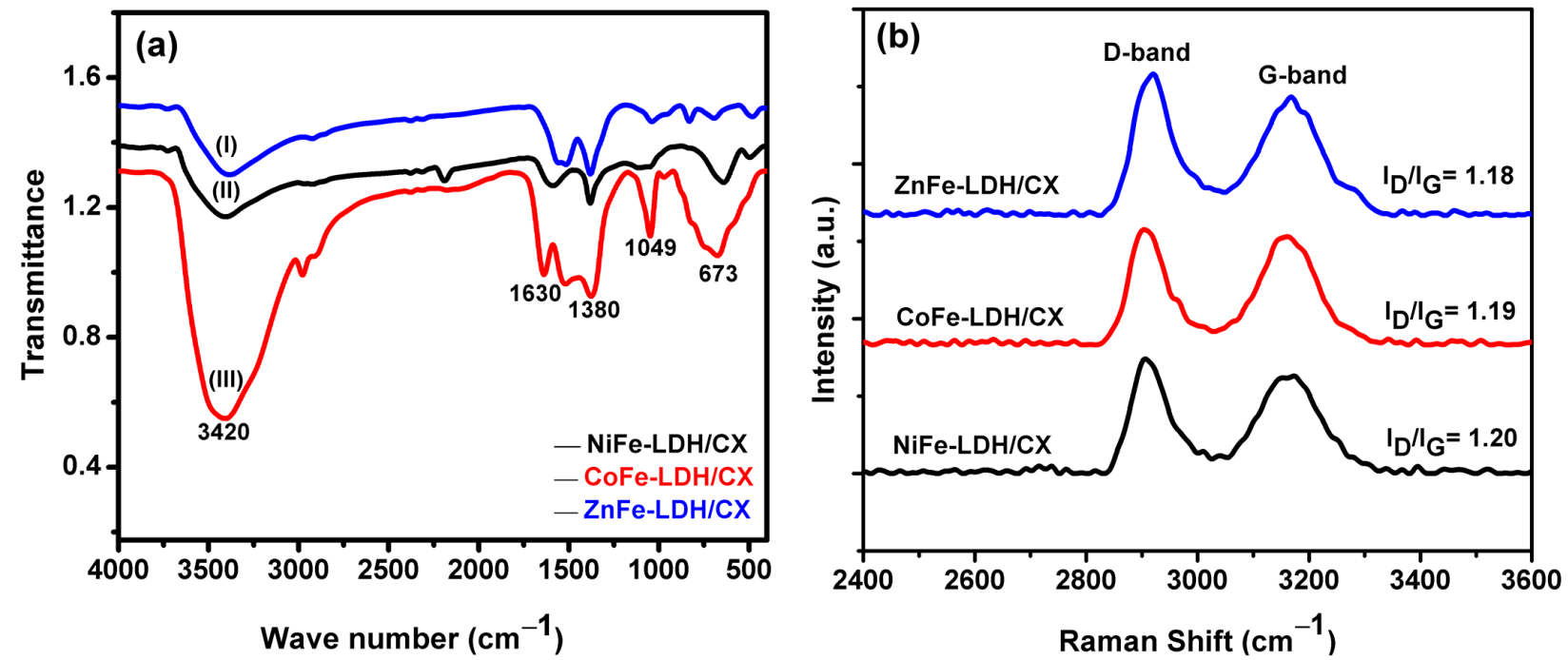

Figure 4. (a) FTIR spectra of hybrid (I) ZnFe-LDH/CX, (II) NiFe-LDH/CX, and (III) CoFe-LDH/CX, and (b) FT-Raman.

The $\mathrm{N}_{2}$ adsorption-desorption isotherms and pore size distributions are represented in Figure 5. Based on IUPAC classification [57], the isotherms for all electrocatalysts are combinations of type I and type IV isotherms [58], indicating that the prepared composite's pores have mainly microporous character and less contribution of mesoporous one. In Figure $5 \mathrm{a}$, there is a higher uptake of $\mathrm{N}_{2}$ at lower relative pressure, indicating micropores filling. Moreover, $\mathrm{NiFe}-\mathrm{LDH}$ and $\mathrm{CoFe}-\mathrm{LDH}$ have hysteresis loops of type $\mathrm{H} 4$ at a moderate relative pressure; narrow slit-like pores in the samples or the internal particles voids have an irregular shape with broad size distributions, as suggested by the BJH method applied to the obtained isotherms, Figure $5 \mathrm{c}[59]$.
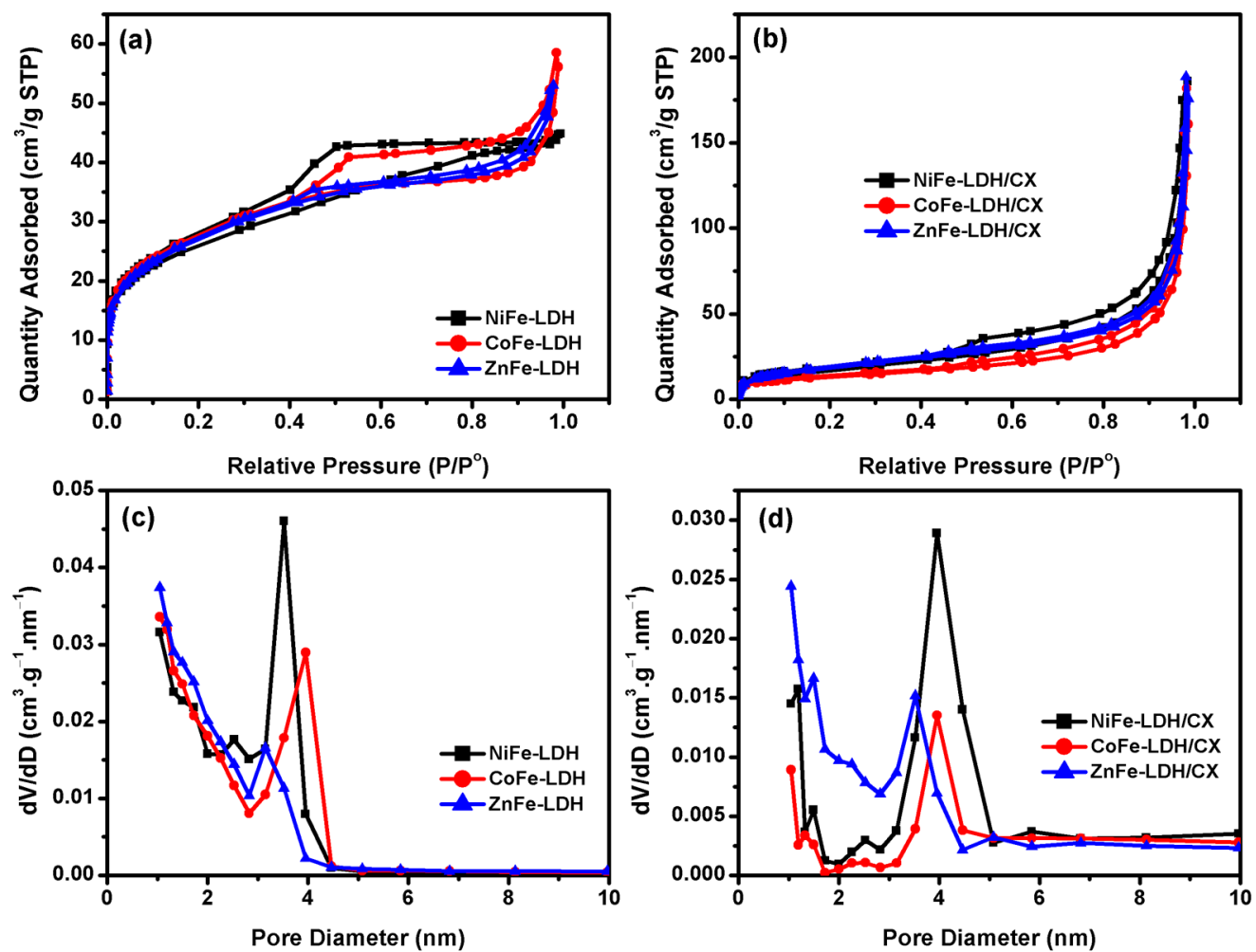

Figure 5. $\mathrm{N}_{2}$ adsorption-desorption isotherms for (a) XFe-LDH, (b) XFe-LDH/CX, (c) and (d) BJH pore size distribution plots of the as-prepared materials. 
The $\mathrm{N}_{2}$ isotherms for LDHs/CX, Figure $5 b$, are also a combination of type I and IV with an increase in the gas adsorption at high relative pressures, which suggests the development of meso-macropore diameter upon intercalation of carbon xerogel between the LDH layers, Figure 5d. The texture characteristics for the samples are shown in Table 2. As it can be seen, there is a decrease in the BET specific surface area $\left(\mathrm{S}_{\mathrm{BET}}\right)$ up on introducing the carbon xerogel between the LDHs layers, which is a confirmation with the development of mesoporous character as observed from the increase in their pore diameter. These hierarchical pore structures are considered to be beneficial in electrocatalytic applications due to minimizing the diffusion barriers [60]. Figure $5 c$,d shows the BJH pore size distribution for the as-prepared sample. In Figure $5 c$, the pore size distributions for LDHs without carbon xerogel are a combination of micro-meso pores with an excess contribution of micropores except for NiFe-LDH. This ratio between micro-meso pores was changed with the incorporation of carbon xerogel into the LDHs structure with the increase in the mesopore diameter, Figure $5 \mathrm{~d}$. The textural characteristics of the samples are collected in Table 2.

Table 2. Textural data of the prepared materials.

\begin{tabular}{lccc}
\hline \multirow{2}{*}{ Sample } & $\mathbf{S}_{\text {BET }}$ & Pore Volume & Mean Pore Diameter \\
\cline { 2 - 4 } & $\mathbf{m}^{\mathbf{2}} / \mathbf{g}$ & $\mathbf{c m}^{\mathbf{3}} / \mathbf{g}$ & $\mathbf{n m}$ \\
\hline $\mathrm{NiFe}-\mathrm{LDH}$ & 98.6 & 0.07 & 2.24 \\
$\mathrm{CoFe}-\mathrm{LDH}$ & 101.2 & 0.09 & 3.60 \\
$\mathrm{ZnFe}-\mathrm{LDH}$ & 99.1 & 0.11 & 4.78 \\
$\mathrm{NiFe}-\mathrm{LDH} / \mathrm{CX}$ & 47.1 & 0.28 & 23.37 \\
$\mathrm{CoFe}-\mathrm{LDH} / \mathrm{CX}$ & 64.4 & 0.34 & 18.16 \\
$\mathrm{ZnFe}-\mathrm{LDH} / \mathrm{CX}$ & 68.6 & 0.32 & 15.93 \\
\hline
\end{tabular}

\subsection{Electrochemical Activity for Methanol Oxidation}

The electrocatalytic performance of the electrocatalysts was investigated using CV, CA, and EIS measurements. Cyclic voltammetry of the prepared nanohybrid electrodes was performed in $1 \mathrm{M} \mathrm{KOH}$ within the potential range of $0-0.7 \mathrm{~V}$ (vs. $\mathrm{Ag} / \mathrm{AgCl}$ ) at different scan rates $(5,10,20,30$, and $40 \mathrm{mV} / \mathrm{s})$. Figure $6 \mathrm{a}, \mathrm{b}$ shows cyclic voltammograms of the prepared nanocomposites at a scan rate of $10 \mathrm{mV} \cdot \mathrm{s}^{-1}$. Figure 6 a shows the cyclic voltammograms of LDHs supported on nickel foam (NF) in which all nanocomposites exhibit higher electrochemical activity than nickel foam alone. Additionally, the highest current density is obtained for $\mathrm{NiFe}-\mathrm{LDH} / \mathrm{NF}$ of $135.8 \mathrm{~mA} \cdot \mathrm{cm}^{-2}$. In addition, introducing carbon xerogel into the LDHs structure improve the electrochemical activity for the composites with the same order, and the current density for $\mathrm{NiFe}-\mathrm{LDH} / \mathrm{CX} / \mathrm{NF}$ reaches $172.6 \mathrm{~mA} \cdot \mathrm{cm}^{-2}$, Figure $6 \mathrm{~b}$. This observation explains the role of carbon xerogel in developing the activity of the prepared catalysts by introducing new channels for ionic diffusion. It is also apparent that pairs of anodic and cathodic redox peaks are obtained for all CV curves, which are mainly attributed to charge transfer processes of solid-state redox [61].

The CV for NiFe-LDH/NF and NiFe-LDH/CX/NF at different scan rates are presented in Figure $6 c, d$, respectively. The increase in current density was noticed on various potential sweeps, implying the formation of an active layer over the catalyst created by the CV cycle. This is likely to be related to the entry of hydroxyl anions into the intermediate layer of the catalyst $[62,63]$. The linear relationship of the square root of the scan rate ranging from 5 to $40 \mathrm{mV} / \mathrm{s}$ with the anodic and cathodic current densities of the redox peaks is shown in Figure 6e. There is an increase in redox reactions with changing the scan rate, and the electrochemical process is controlled by the spread of $\mathrm{OH}$ in the mesopore cavity [35]. 


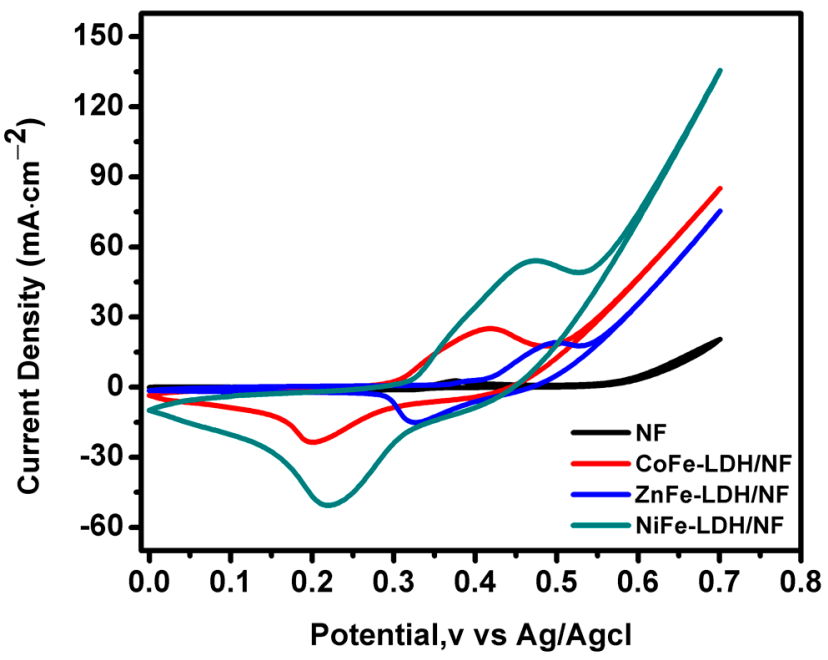

(a)

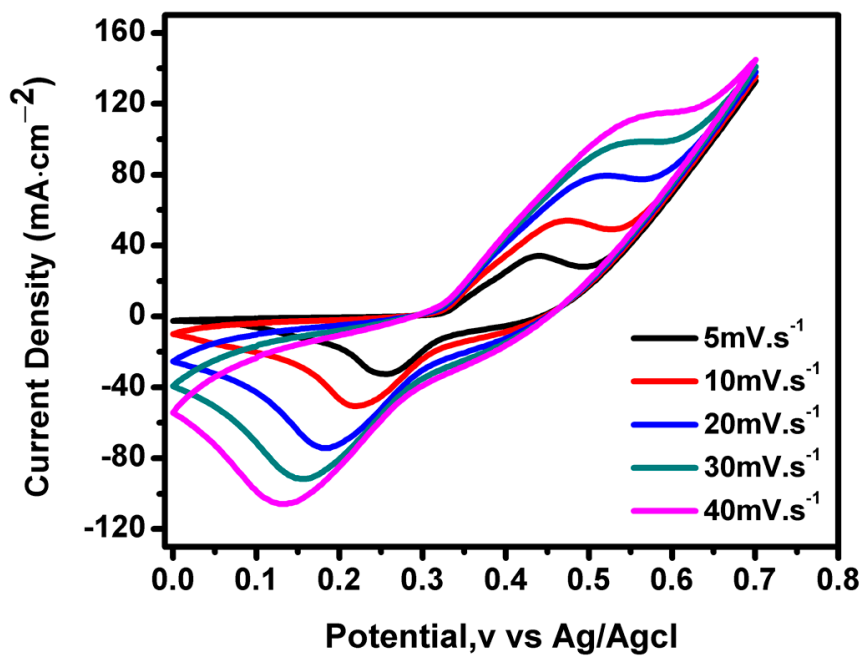

(c)

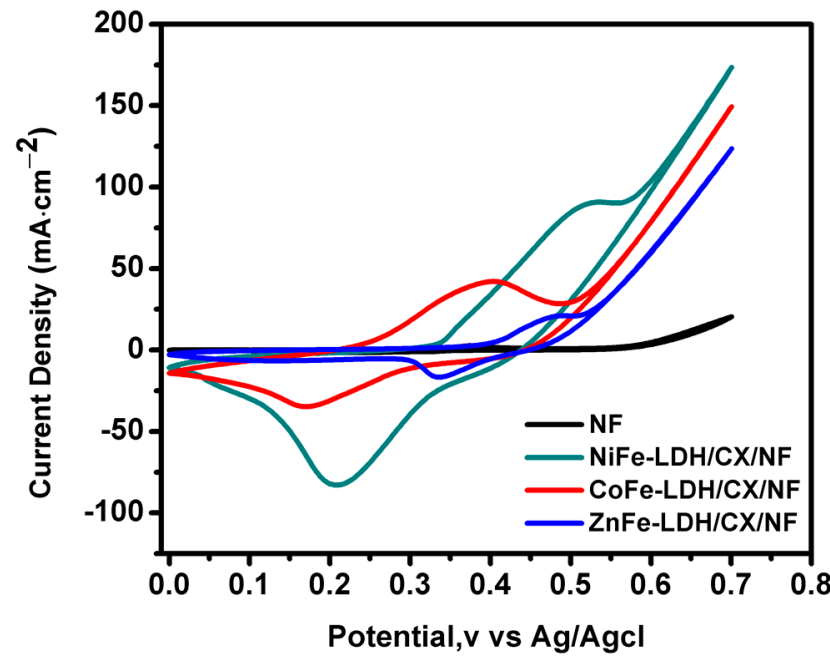

(b)

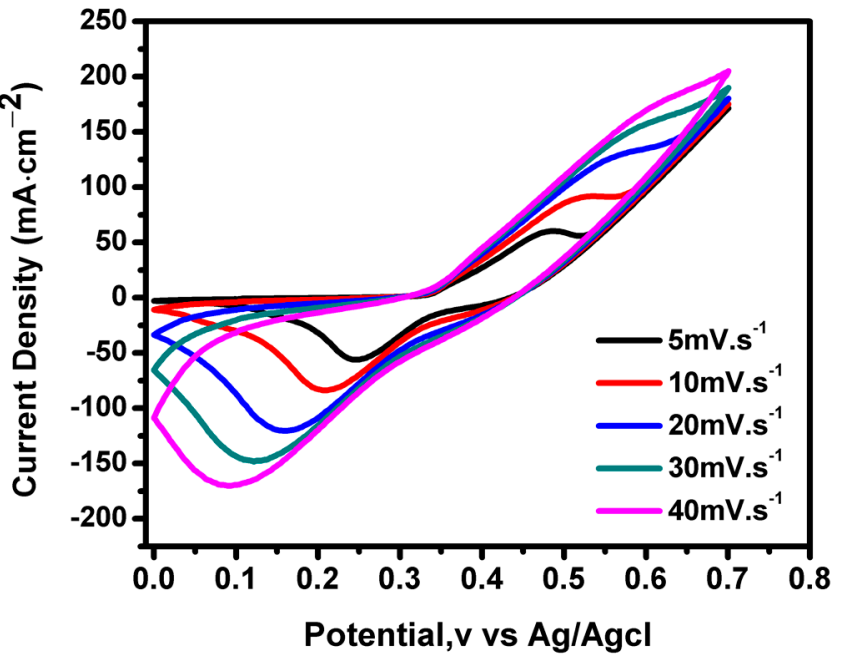

(d)

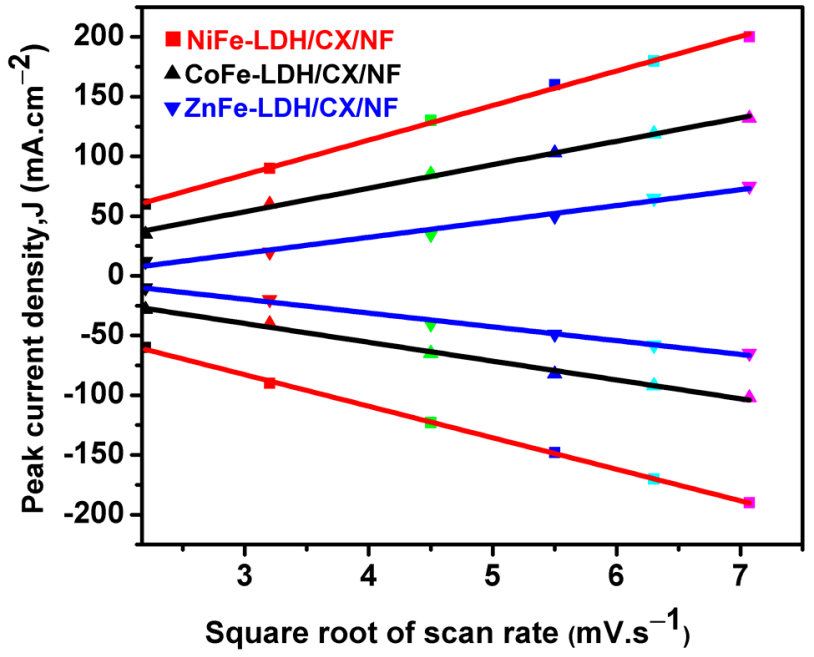

(e)

Figure 6. CVs at $1 \mathrm{M} \mathrm{KOH}$ of (a) LDHs/NF at $10 \mathrm{mV} / \mathrm{s}$, (b) LDHs/CX/NF at $10 \mathrm{mV} / \mathrm{s}$, (c) NiFe-LDH/NF at different scan rates, and (d) NiFe-LDH/CX/NF at different scan rates. (e) Linear relationship between the forward/backward anodic peak currents and the square root of the scan rate for all nanohybrids with $\mathrm{CX}$. 
Figure 7a shows the $\mathrm{CV}$ curves of the electrodes in $1 \mathrm{M} \mathrm{KOH}$ and $0.5 \mathrm{M} \mathrm{MeOH}$ at a scan rate of $10 \mathrm{mV} / \mathrm{s}$. The electrochemical characteristics indicate that there is an increase in the current density after the addition of methanol, indicating oxidation of methanol on the surface of the prepared hybrids. Moreover, LDHs/CX composites have a higher activity to methanol oxidation due to the higher surface area delivered by the addition of $\mathrm{CX}$ to the composites, Figure $7 \mathrm{~b}$. The $\mathrm{CV}$ curves for NiFe-LDH/NF and NiFe$\mathrm{LDH} / \mathrm{CX} / \mathrm{NF}$ at different scan rates are shown in Figure $7 \mathrm{c}, \mathrm{d}$, respectively. A higher anodic oxidation current density for the electro-oxidation of methanol reaches $400 \mathrm{~mA} \cdot \mathrm{cm}^{-2}$ at the $\mathrm{NiFe}-\mathrm{LDH} / \mathrm{CX} / \mathrm{NF}$ compared to $90 \mathrm{~mA} \cdot \mathrm{cm}^{-2}$ at NF, Figure $7 \mathrm{~b}$, indicating a greater electrocatalytic response of NiFe-LDH/CX/NF electrode for electro-oxidation of methanol, which assures that $\mathrm{CX}$ can reduce agglomeration of LDH and form new material with higher electrochemical activity [35].

Interestingly, there was a relationship between the electrocatalytic performance of the nanohybrid LDH for the oxidation of methanol and the type of divalent cation. The better performance of the NiFe-LDH/CX/NF electrode has been related to the intrinsic activity of this compound, combined with its mesoporous structure and wide pore width that improve mass transport and transfer of electrons. Moreover, according to XRD data, NiFe$\mathrm{LDH} / \mathrm{CX}$ has the least average crystallite size among the nanocomposites of LDHs/CX. Different studies found a relationship between electrode activity and its crystallite size [49]. The literature has reported that defective $\mathrm{Ni}(\mathrm{OH})_{2}$ species promote $\mathrm{OH}^{-}$switching from $\mathrm{Ni}(\mathrm{OH})_{2}$ to adjacent nanocrystals by forming new channels and active sites for $\mathrm{OH}^{-}$adsorption and developing removal of carbon species, $\mathrm{CO}$, which poisons the surfaces of the catalyst and increases the electrocatalytic activity of the LDH nanohybrid [64]. Figure 7e exhibits a linear relationship between the square root of the scan rate $5-40 \mathrm{mV} \cdot \mathrm{s}^{-1}$ and the catalytic current density. The results indicate that the electro-oxidation of methanol on the NiFe-LDH/CX/NF is a surface controlled process [65]. The highly electroactive response of $\mathrm{NiFe}-\mathrm{LDH} / \mathrm{CX} / \mathrm{NF}$ when comparing it with $\mathrm{NiFe}-\mathrm{LDH} / \mathrm{NF}$ is inferred from its high anodic and cathodic current densities. This enhancement in the electrocatalytic activity is observed although the specific surface area and cumulative pore volume of other nanohybrids are higher than those of NiFe-LDH/CX/NF, Table 2, and the enhancement in the electrocatalytic activity of our modified $\mathrm{NiFe}-\mathrm{LDH} / \mathrm{CX} / \mathrm{NF}$ can also be attributed to the synergistic effect between NiFe-LDH and CX during the preparation of the nanocomposites, low crystallite size, and its unique nanostars morphology.

Interestingly, the electrocatalytic activity of our modified NiFe-LDH/CX/NF mesoporous electrode is higher than that previously reported for the electro-oxidation of methanol [66], as presented in Table 3. Most of the reported studies for methanol oxidation explain the activity of the electrocatalysts to the surface area of the catalyst. The catalyst with a higher surface area has higher activity for the oxidation of methanol. Although our new NiFe-LDH/CX/NF catalyst has a small specific surface area compared to the other reported electrodes, it has an excellent activity for MOR. The correlation between pore geometry, crystallite size, and morphology also has a great influence on electrode activity.

Table 3. Comparison of current densities, electrolyte, and applied potential with several reported electrocatalysts for methanol oxidation.

\begin{tabular}{|c|c|c|c|c|}
\hline Electrocatalyst & Electrolyte & Applied Voltage & Current Density & Ref. \\
\hline $\mathrm{NiFe}-\mathrm{LDH} / \mathrm{CX} / \mathrm{NF}$ & $1.0 \mathrm{M} \mathrm{KOH} / 0.5 \mathrm{M} \mathrm{CH}_{3} \mathrm{OH}$ & $0-0.7 \mathrm{~V}$ vs. $\mathrm{Ag} / \mathrm{AgCl}$ & $400 \mathrm{~mA} \cdot \mathrm{cm}^{-2}$ & This work \\
\hline 3D NiCr-LDH/rGO & $1.0 \mathrm{M} \mathrm{KOH} / 3.0 \mathrm{M} \mathrm{CH}_{3} \mathrm{OH}$ & $0-0.6 \mathrm{~V}$ vs. $\mathrm{Ag} / \mathrm{AgCl}$ & $2.2 \mathrm{~mA} \cdot \mathrm{cm}^{-2}$ & [27] \\
\hline Microsphere $\mathrm{Co}_{3} \mathrm{O}_{4} / \mathrm{NF}$ & $1.0 \mathrm{M} \mathrm{KOH} / 0.5 \mathrm{M} \mathrm{CH}_{3} \mathrm{OH}$ & $0-0.6 \mathrm{~V}$ vs. $\mathrm{Hg} / \mathrm{HgO}$ & $36 \mathrm{~A} \cdot \mathrm{g}^{-1}$ & [59] \\
\hline $\mathrm{Co}(\mathrm{OH})_{2} / \mathrm{NF}$ & $1.0 \mathrm{M} \mathrm{KOH} / 0.5 \mathrm{M} \mathrm{CH}_{3} \mathrm{OH}$ & $0-0.5 \mathrm{~V}$ vs. SCE & $150 \mathrm{~A} \cdot \mathrm{g}^{-1}$ & {$[44]$} \\
\hline Mn doped $\mathrm{Ni}(\mathrm{OH})_{2}$ & $1.0 \mathrm{M} \mathrm{KOH} / 0.5 \mathrm{M} \mathrm{CH}_{3} \mathrm{OH}$ & $1-2$ V vs. RHE & $20 \mathrm{~A} \cdot \mathrm{g}^{-1}$ & [3] \\
\hline 3D nickel networks & $1.0 \mathrm{M} \mathrm{NaOH} / 1.0 \mathrm{M} \mathrm{CH}_{3} \mathrm{OH}$ & $0-0.8 \mathrm{~V}$ vs. $\mathrm{Hg} / \mathrm{HgO}$ & $175 \mathrm{~mA} \cdot \mathrm{cm}^{-2}$ & [12] \\
\hline $\mathrm{NiCO}_{2} \mathrm{O}_{4} / \mathrm{CX}$ & $1.0 \mathrm{M} \mathrm{KOH} / 0.5 \mathrm{M} \mathrm{CH}_{3} \mathrm{OH}$ & $0-0.6 \mathrm{~V}$ vs. $\mathrm{Ag} / \mathrm{AgCl}$ & $98 \mathrm{~mA} \cdot \mathrm{cm}^{-2}$ & [35] \\
\hline
\end{tabular}




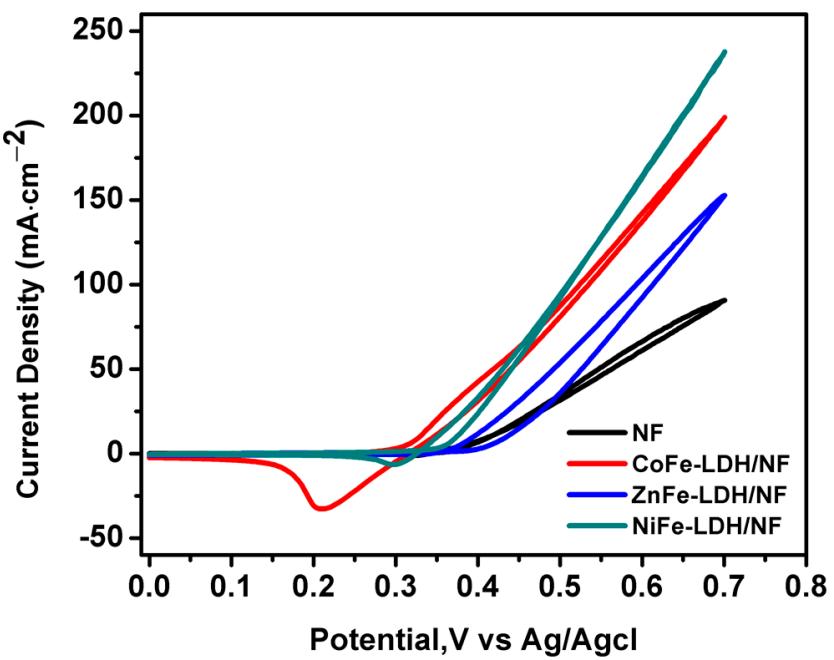

(a)

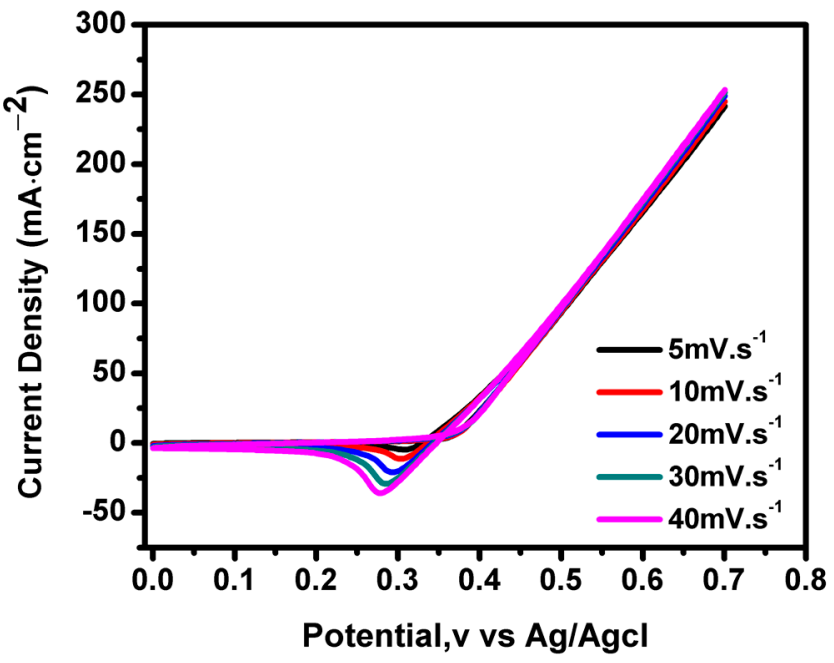

(c)

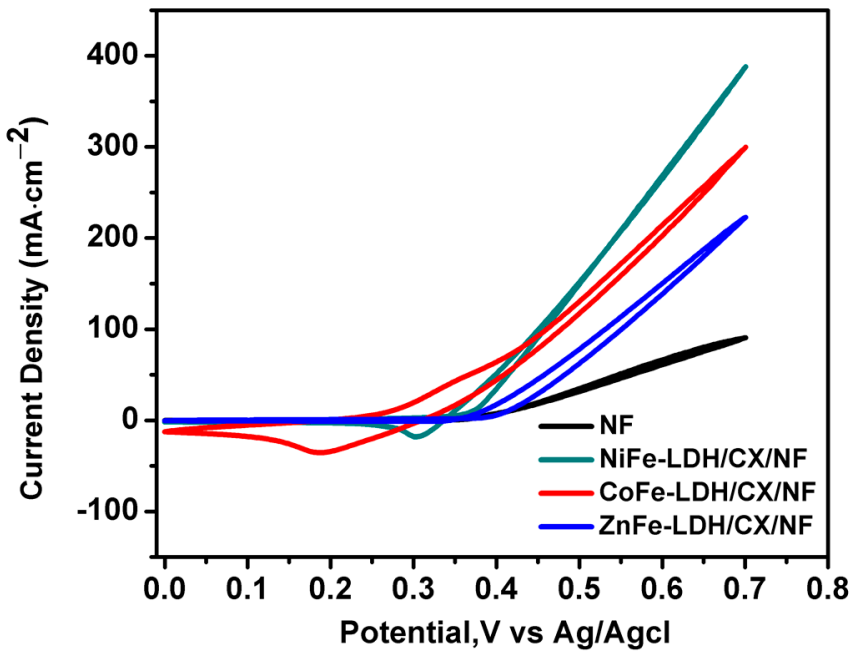

(b)

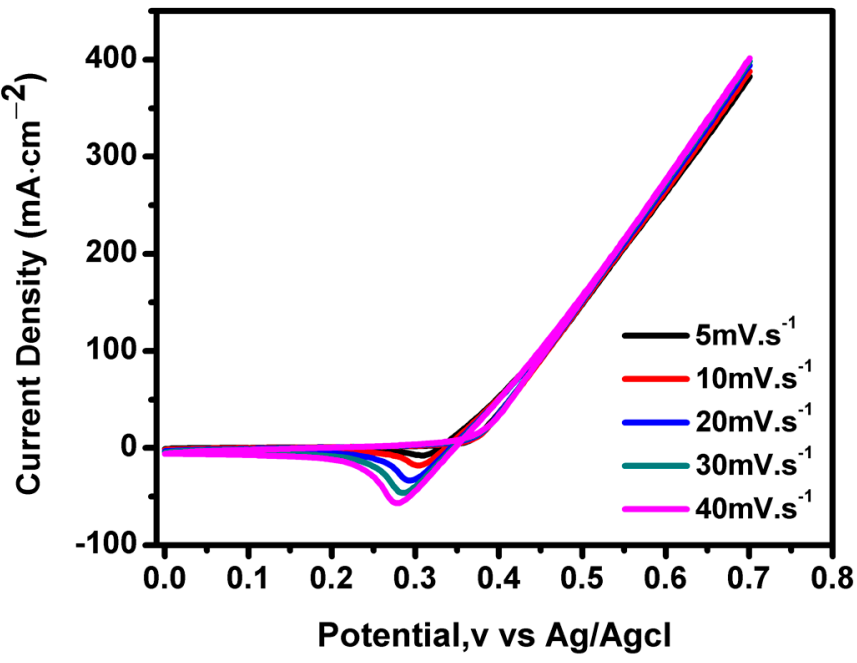

(d)

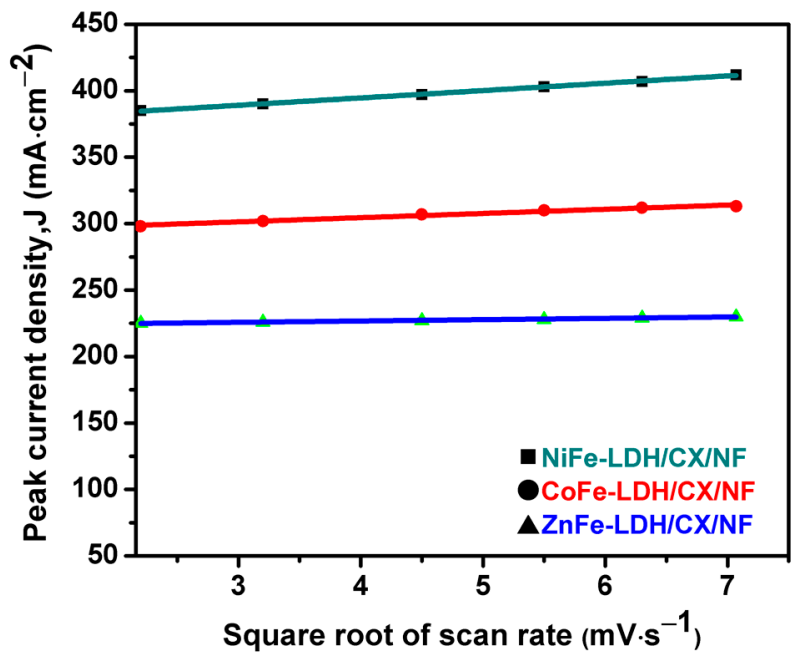

(e)

Figure 7. $\mathrm{CVs}$ at $1 \mathrm{M} \mathrm{KOH}+0.5 \mathrm{M} \mathrm{MeOH}$ of (a) LDHs/NF at $10 \mathrm{mV} / \mathrm{s},(\mathbf{b}) \mathrm{LDHs} / \mathrm{CX} / \mathrm{NF}$ at $10 \mathrm{mV} / \mathrm{s},(\mathbf{c}) \mathrm{NiFe}-\mathrm{LDH} / \mathrm{NF}$ at different scan rates, and (d) NiFe-LDH/CX/NF at different scan rates. (e) Linear relationship between the anodic peak currents and the square root of the scan rate for all nanohybrids with $\mathrm{CX}$. 
The electrochemical stability of the prepared materials is another important issue to consider in practical applications. Figure 8a shows the repetitive 100-cycle test for $\mathrm{NiFe}$ $\mathrm{LDH} / \mathrm{CX} / \mathrm{NF}$ at a scan rate of $50 \mathrm{mV} \cdot \mathrm{s}^{-1}$ in $1.0 \mathrm{M} \mathrm{KOH}$ with $0.5 \mathrm{M} \mathrm{CH}_{3} \mathrm{OH}$ solution at room temperature. There is almost no change in the electrocatalytic activity towards the oxidation of methanol that can be observed after 100 cycles, which indicates exceptional stability for this nanohybrid.

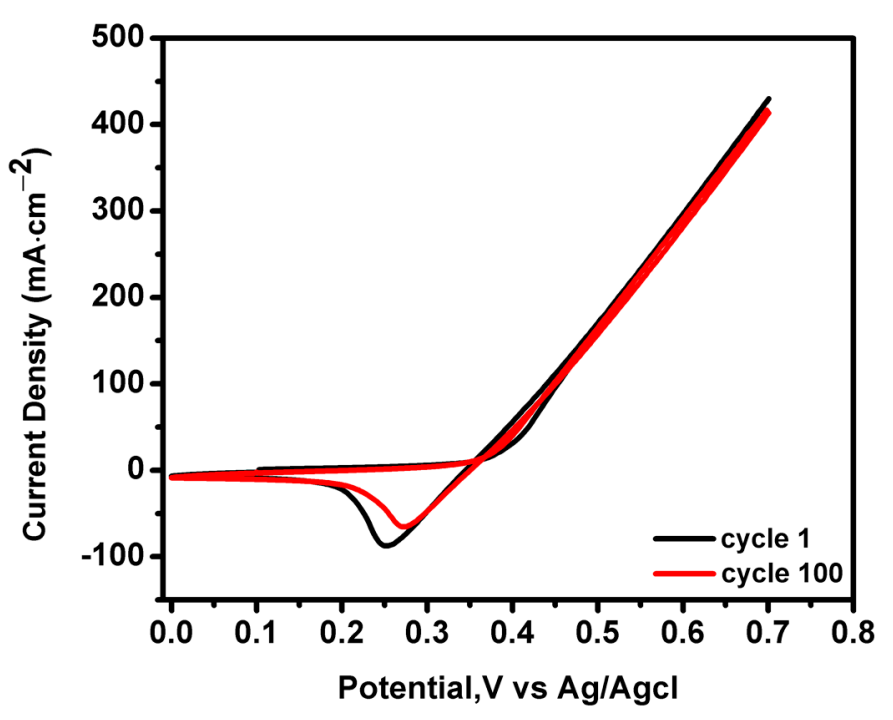

(a)

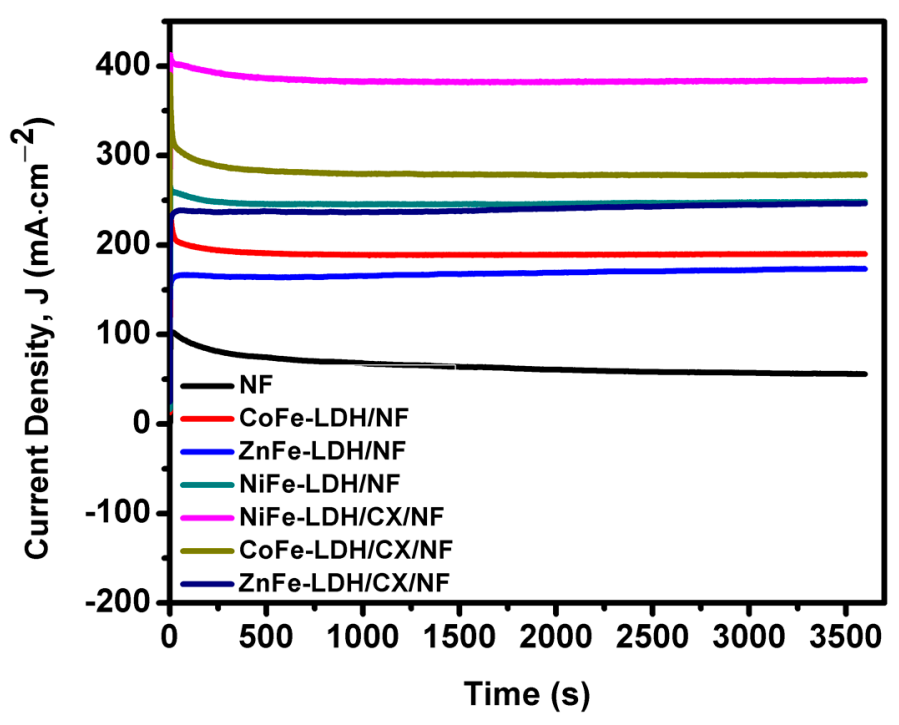

(b)

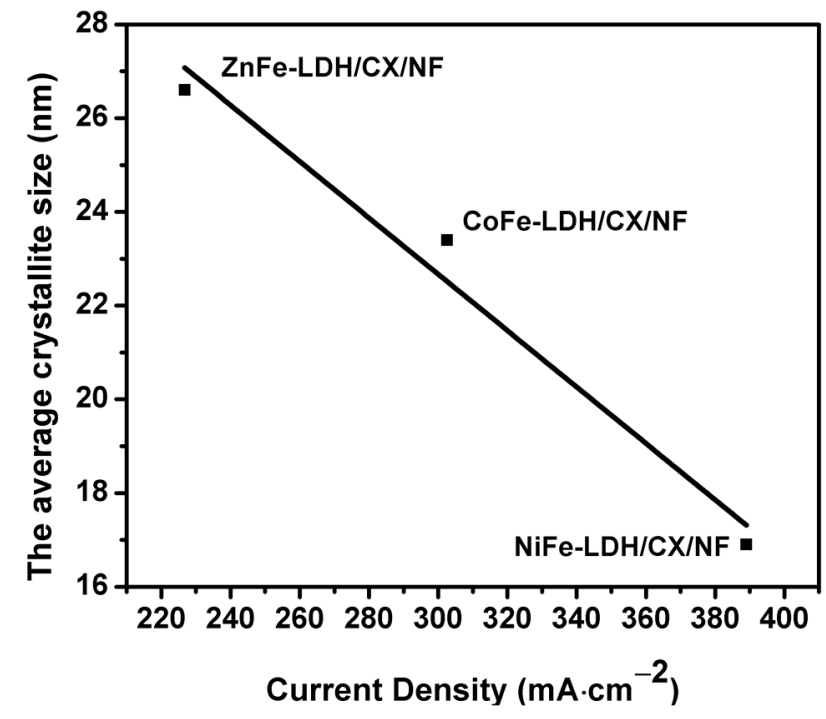

(c)

Figure 8. (a) Repetitive 100th cycle of NiFe-LDH/CX/NF in $1.0 \mathrm{M} \mathrm{KOH}+0.5 \mathrm{M} \mathrm{CH}_{3} \mathrm{OH}$ at a scan rate of $40 \mathrm{mV} / \mathrm{s}$. (b) Chronoamperometric response of the synthesized electrocatalysts in $1.0 \mathrm{M} \mathrm{KOH}+0.5 \mathrm{M} \mathrm{CH}_{3} \mathrm{OH}$ at $0.7 \mathrm{~V}$ and (c) the crystallite particle size of the modified electrodes versus their electrochemical activity.

Figure $8 \mathrm{~b}$ characterizes the chrono-amperometric curves of nanohybrids in $1 \mathrm{M} \mathrm{KOH}$ and $0.5 \mathrm{M}$ methanol at a constant potential of $0.6 \mathrm{~V}$ vs. $\mathrm{Ag} / \mathrm{AgCl}$ for $1 \mathrm{~h}$. It can be seen that the obtained current densities for all catalytic systems are nearly stable after $3600 \mathrm{~s}$. This could be assigned to the formation of reactive intermediates such as CO and $\mathrm{COH}$ during the oxidation reaction of methanol [67]. During the test process, all electrocatalysts were stable, but it was noted that the current density obtained with the $\mathrm{NiFe}-\mathrm{LDH} / \mathrm{CX} / \mathrm{NF}$ catalyst was higher than others. This long-term stability could be 
attributed to its mesoporous structure, which causes the fast transformation of the adsorbed intermediates into products that increase the catalytic activity of the nanohybrids $[10,68]$.

On the other hand, taking into account the effect of the crystallite size of the prepared materials on the electrochemical activity to methanol oxidation (Table 1), a clear relationship can be observed: the smaller the crystallite size, the higher the current density delivered, Figure 8c. In our opinion, the results of this work exhibit clear evidence that crystallite size, electrode morphology, and mesopore diameter development are crucial parameters involved in the electro-oxidation of methanol.

\section{Conclusions}

Series of layered double hydroxides with different divalent cations of $\mathrm{Ni}, \mathrm{Co}$, and $\mathrm{Zn}$ - iron LDHs were successfully prepared. All electrocatalysts show a very good activity to methanol oxidation, where NiFe-LDH/NF is the best one. Furthermore, introducing carbon xerogel into the LDHs structure significantly improves the electrocatalysts activity to methanol electrooxidation. This development can be attributed to the 3D structure of carbon xerogel, which facilitates the ionic diffusion inside the carbon matrix, resulting in higher $\mathrm{OH}^{-}$adsorption. $\mathrm{NiFe}-\mathrm{LDH} / \mathrm{CX} / \mathrm{NF}$ is the best catalyst for methanol oxidation with a current density of $400 \mathrm{~mA} \cdot \mathrm{cm}^{-2}$ with excellent stability. Additionally, there is a strong influence of the electrocatalysts crystallite size on the activity of methanol oxidation. The smaller the crystallite size, the higher current densities were obtained. Moreover, the morphology change of the electrocatalysts with the divalent cations has an influence on their activity towards MOR. These results suggest the potential use of LDHs/CX/NF electrocatalysts in proton-exchange membrane fuel cells because they are inexpensive and have high activity and excellent stability.

Author Contributions: Conceptualization, A.A. and M.M.E.-D.; methodology, G.M.A.; validation, A.F.P.-C.; formal analysis, A.F.P.-C.; investigation, A.A.; data curation, A.A.F. and A.F.P.-C.; writingoriginal draft preparation, G.M.A.; writing-review and editing, A.A.; visualization, A.A.F.; supervision, A.A., A.A.F. and M.M.E.-D.; project administration, A.A.; funding acquisition, M.M.E.-D. All authors have read and agreed to the published version of the manuscript.

Funding: This research was funded by Beni-Suef University, university performance development center support and project finance office, grant number BSU-CP7-19010.

Institutional Review Board Statement: Not applicable.

Informed Consent Statement: Not applicable.

Data Availability Statement: The data presented in this study are available on request from the corresponding author.

Conflicts of Interest: The authors declare no conflict of interest.

\section{References}

1. Jia, Z.; Wang, Y.; Qi, T. Hierarchical Ni-Fe layered double hydroxide $/ \mathrm{MnO}_{2}$ sphere architecture as an efficient noble metal-free electrocatalyst for ethanol electro-oxidation in alkaline solution. RSC Adv. 2015, 5, 83314-83319. [CrossRef]

2. Carrette, L.; Friedrich, K.A.; Stimming, U. Fuel cells: Principles, types, fuels, and applications. ChemPhysChem 2000, 1, 162-193. [CrossRef]

3. Dong, B.; Li, W.; Huang, X.; Ali, Z.; Zhang, T.; Yang, Z.; Hou, Y. Fabrication of hierarchical hollow Mn doped Ni(OH) 2 nanostructures with enhanced catalytic activity towards electrochemical oxidation of methanol. Nano Energy 2019, 55, 37-41. [CrossRef]

4. Tsang, A.C.H.; Hui, K.S.; Ren, L. Deposition of Pd/graphene aerogel on nickel foam as a binder-free electrode for direct electro-oxidation of methanol and ethanol. J. Mater. Chem. A 2014, 2, 17986-17993. [CrossRef]

5. Sheikh-Mohseni, M.A.; Hassanzadeh, V.; Habibi, B. Reduced graphene oxide supported bimetallic Ni-Co nanoparticles composite as an electrocatalyst for oxidation of methanol. Solid State Sci. 2019, 98, 106022. [CrossRef]

6. Tu, W.; Sun, Y.; Wu, D.; Wang, H.; Huang, H.; Shao, M.; Liu, Y.; Kang, Z. Cobalt oxyhydroxide and carbon dots modified by platinum as superior electrocatalyst for methanol oxidation. Mater. Chem. Phys. 2019, 225, 64-71. [CrossRef] 
7. Askari, M.B.; Beheshti-Marnani, A.; Seifi, M.; Rozati, S.M.; Salarizadeh, P. $\mathrm{Fe}_{3} \mathrm{O}_{4} @ \mathrm{MoS}_{2} / \mathrm{RGO}$ as an effective nano-electrocatalyst toward electrochemical hydrogen evolution reaction and methanol oxidation in two settings for fuel cell application. J. Colloid Interface Sci. 2019, 537, 186-196. [CrossRef] [PubMed]

8. Liu, Q.; Lin, Y.; Fan, J.; Lv, D.; Min, Y.; Wu, T.; Xu, Q. Well-dispersed palladium nanoparticles on three-dimensional hollow $\mathrm{N}$-doped graphene frameworks for enhancement of methanol electro-oxidation. Electrochem. Commun. 2016, 73, 75-79. [CrossRef]

9. Chu, D.; Jiang, R. Novel electrocatalysts for direct methanol fuel cells. Solid State Ionics 2002, 148, 591-599. [CrossRef]

10. Zhang, F.; Wang, Z.; Xu, K.Q.; Xia, J.; Liu, Q.; Wang, Z. Highly dispersed ultrafine Pt nanoparticles on nickel-cobalt layered double hydroxide nanoarray for enhanced electrocatalytic methanol oxidation. Int. J. Hydrog. Energy 2018, 43, 16302-16310. [CrossRef]

11. Cao, J.; Chen, H.; Zhang, X.; Zhang, Y.; Liu, X. Graphene-supported platinum/nickel phosphide electrocatalyst with improved activity and stability for methanol oxidation. RSC Adv. 2018, 8, 8228-8232. [CrossRef]

12. Guo, X.; Liang, T.; Zhang, D.; Zhang, M.; Lin, Y.; Lai, C. Facile fabrication of 3D porous nickel networks for electro-oxidation of methanol and ethanol in alkaline medium. Mater. Chem. Phys. 2019, 221, 390-396. [CrossRef]

13. Jia, Z.; Wang, Y.; Qi, T. Pd nanoparticles supported on $\mathrm{Mg}-\mathrm{Al}-\mathrm{CO}_{3}$ layered double hydroxide as an effective catalyst for methanol electro-oxidation. RSC Adv. 2015, 5, 62142-62148. [CrossRef]

14. Sreekanth, T.; Ramaraghavulu, R.; Vattikuti, S.P.; Shim, J.; Yoo, K. Microwave synthesis: $\mathrm{ZnCo}_{2} \mathrm{O}_{4}$ NPs as an efficient electrocatalyst in the methanol oxidation reaction. Mater. Lett. 2019, 253, 450-453. [CrossRef]

15. Tan, Y.; Zhang, Y.; Wang, X.; Zeng, L.; Luo, F.; Liu, A. Amorphous nickel coating on carbon nanotubes supported Pt nanoparticles as a highly durable and active electrocatalyst for methanol oxidation reaction. J. Electroanal. Chem. 2020, 856, 113739. [CrossRef]

16. Sun, H.; Liu, J.; Zhang, C.; Yuan, Q.; Ye, Y.; Yan, W.; Tian, Z.; Liang, C. S,N dual-doped carbon nanotubes as substrate to enhance the methanol oxidation performance of $\mathrm{NiO}$ nanoparticles. Carbon 2019, 152, 114-119. [CrossRef]

17. Yang, L.; Zeng, X.; Wang, W.; Cao, D. Recent Progress in MOF-Derived, Heteroatom-Doped Porous Carbons as Highly Efficient Electrocatalysts for Oxygen Reduction Reaction in Fuel Cells. Adv. Funct. Mater. 2018, 28, 1704537. [CrossRef]

18. Vlamidis, Y.; Fiorilli, S.L.; Giorgetti, M.; Gualandi, I.; Scavetta, E.; Tonelli, D. Role of Fe in the oxidation of methanol electrocatalyzed by Ni based layered double hydroxides: X-ray spectroscopic and electrochemical studies. RSC Adv. 2016, 6, 110976-110985. [CrossRef]

19. Long, X.; Wang, Z.; Xiao, S.; An, Y.; Yang, S. Transition metal based layered double hydroxides tailored for energy conversion and storage. Mater. Today 2016, 19, 213-226. [CrossRef]

20. Jiang, J.; Zhang, A.; Li, L.; Ai, L. Nickel-cobalt layered double hydroxide nanosheets as high-performance electrocatalyst for oxygen evolution reaction. J. Power Sources 2015, 278, 445-451. [CrossRef]

21. Wang, Y.; Ji, H.; Peng, W.; Liu, L.; Gao, F.; Li, M. Gold nanoparticle-coated Ni/Al layered double hydroxides on glassy carbon electrode for enhanced methanol electro-oxidation. Int. J. Hydrog. Energy 2012, 37, 9324-9329. [CrossRef]

22. Wang, H.; Chen, Y.; Xie, W.; Han, X.; Feng, Q.; Jiang, R.; Shang, H.; Zhang, F.; Gao, L.; Wang, Z. Construction of Highly Active $\mathrm{Pt} / \mathrm{Ni}$-Fe Layered Double Hydroxide Electrocatalyst towards Methanol Oxidation in Alkaline Medium. Int. J. Electrochem. Sci. 2019, 14, 7961-7972. [CrossRef]

23. Wang, Y.; Zhang, D.; Peng, W.; Liu, L.; Li, M. Electrocatalytic oxidation of methanol at Ni-Al layered double hydroxide film modified electrode in alkaline medium. Electrochim. Acta 2011, 56, 5754-5758. [CrossRef]

24. Wang, Y.; Zhang, D.; Tang, M.; Xu, S.; Li, M. Electrocatalysis of gold nanoparticles/layered double hydroxides nanocomposites toward methanol electro-oxidation in alkaline medium. Electrochim. Acta 2010, 55, 4045-4049. [CrossRef]

25. Septiani, N.L.W.; Kaneti, Y.V.; Guo, Y.; Yuliarto, B.; Jiang, X.; Ide, Y.; Nugraha, N.; Dipojono, H.K.; Yu, A.; Sugahara, Y.; et al. Holey Assembly of Two-Dimensional Iron-Doped Nickel-Cobalt Layered Double Hydroxide Nanosheets for Energy Conversion Application. ChemSusChem 2020, 13, 1645-1655. [CrossRef]

26. Shen, J.; Ye, S.; Xu, X.; Liang, J.; He, G.; Chen, H. Reduced graphene oxide based NiCo layered double hydroxide nanocomposites: An efficient catalyst for epoxidation of styrene. Inorg. Chem. Commun. 2019, 104, 219-222. [CrossRef]

27. Gamil, S.; Antuch, M.; Zedan, I.T.; El Rouby, W.M.A. 3D NiCr-layered double hydroxide/reduced graphene oxide sand rose-like structure as bifunctional electrocatalyst for methanol oxidation. Colloids Surf. A Physicochem. Eng. Aspects 2020, 602, 125067. [CrossRef]

28. Park, C.; Lee, J.-H.; Seo, J.; Ran, W.; Whang, D.; Hwang, S.; Kim, Y.-J. Graphene/PVDF Composites for Ni-rich Oxide Cathodes toward High-Energy Density Li-ion Batteries. Materials 2021, 14, 2271. [CrossRef]

29. Kamedulski, P.; Lukaszewicz, J.; Witczak, L.; Szroeder, P.; Ziolkowski, P. The Importance of Structural Factors for the Electrochemical Performance of Graphene/Carbon Nanotube/Melamine Powders towards the Catalytic Activity of Oxygen Reduction Reaction. Materials 2021, 14, 2448. [CrossRef]

30. Chae, G.; Youn, D.; Lee, J. Nanostructured Iron Sulfide/N, S Dual-Doped Carbon Nanotube-Graphene Composites as Efficient Electrocatalysts for Oxygen Reduction Reaction. Materials 2021, 14, 2146. [CrossRef] [PubMed]

31. Lu, Y.; Zhang, Z.; Wang, H.; Wang, Y. Toward efficient single-atom catalysts for renewable fuels and chemicals production from biomass and $\mathrm{CO}_{2}$. Appl. Catal. B Environ. 2021, 292, 120162. [CrossRef]

32. Pérez-Cadenas, M.; Moreno-Castilla, C.; Carrasco-Marín, F.; Pérez-Cadenas, A.F. Surface chemistry, porous texture, and morphology of N-doped carbon xerogels. Langmuir 2008, 25, 466-470. [CrossRef]

33. Pekala, R.W. Organic aerogels from the polycondensation of resorcinol with formaldehyde. J. Mater. Sci. 1989, $24,3221-3227$. [CrossRef] 
34. Abdelwahab, A.; Castelo-Quibén, J.; Pérez-Cadenas, M.; Elmouwahidi, A.; Maldonado-Hódar, F.J.; Carrasco-Marín, F.; PérezCadenas, A.F. Cobalt-Doped Carbon Gels as Electro-Catalysts for the Reduction of $\mathrm{CO}_{2}$ to Hydrocarbons. Catalysts 2017, 7, 25. [CrossRef]

35. El-Deeb, M.M.; El Rouby, W.M.A.; Abdelwahab, A.; Farghali, A.A. Effect of pore geometry on the electrocatalytic performance of nickel cobaltite/carbon xerogel nanocomposite for methanol oxidation. Electrochim. Acta 2018, 259, 77-85. [CrossRef]

36. Li, D.; Zang, J.; Zhang, J.; Ao, K.; Wang, Q.; Dong, Q.; Wei, Q.J.M. Sol-gel synthesis of carbon xerogel-ZnO composite for detection of catechol. Materials 2016, 9, 282. [CrossRef]

37. Wasfey, M.A.; Abdelwahab, A.; Carrasco-Marín, F.; Pérez-Cadenas, A.F.; Abdullah, H.H.; Yahia, I.S.; Farghali, A.A. Nickel Cobaltite Functionalized Silver Doped Carbon Xerogels as Efficient Electrode Materials for High Performance Symmetric Supercapacitor. Materials 2020, 13, 4906. [CrossRef]

38. Du, Y.Y.; Jin, Q.; Feng, J.T.; Zhang, N.; He, Y.F.; Li, D.Q. Flower-like Au/Ni-Al hydrotalcite with hierarchical pore structure as a multifunctional catalyst for catalytic oxidation of alcohol. Catal. Sci. Technol. 2015, 5, 3216-3225. [CrossRef]

39. Li, Z.; Shao, M.; An, H.; Wang, Z.; Xu, S.; Wei, M.; Evans, D.G.; Duan, X. Fast electrosynthesis of Fe-containing layered double hydroxide arrays toward highly efficient electrocatalytic oxidation reactions. Chem. Sci. 2015, 6, 6624-6631. [CrossRef]

40. Gamil, S.; El Rouby, W.M.A.; Antuch, M.; Zedan, I.T. Nanohybrid layered double hydroxide materials as efficient catalysts for methanol electrooxidation. RSC Adv. 2019, 9, 13503-13514. [CrossRef]

41. Verlato, E.; Cattarin, S.; Comisso, N.; Gambirasi, A.; Musiani, M.; Gomez, L.V. Preparation of Pd-Modified Ni Foam Electrodes and Their Use as Anodes for the Oxidation of Alcohols in Basic Media. Electrocatalysis 2012, 3, 48-58. [CrossRef]

42. Jadhav, H.S.; Roy, A.; Chung, W.-J.; Gil Seo, J. Growth of urchin-like $\mathrm{ZnCo}_{2} \mathrm{O}_{4}$ microspheres on nickel foam as a binder-free electrode for high-performance supercapacitor and methanol electro-oxidation. Electrochim. Acta 2017, 246, 941-950. [CrossRef]

43. Yu, M.; Chen, J.; Liu, J.; Li, S.; Ma, Y.; Zhang, J.; An, J. Mesoporous $\mathrm{NiCo}_{2} \mathrm{O}_{4}$ nanoneedles grown on 3D graphene-nickel foam for supercapacitor and methanol electro-oxidation. Electrochim. Acta 2015, 151, 99-108. [CrossRef]

44. Roy, A.; Jadhav, H.S.; Thorat, G.M.; Gil Seo, J. Electrochemical growth of $\mathrm{Co}(\mathrm{OH})_{2}$ nanoflakes on Ni foam for methanol electro-oxidation. New J. Chem. 2017, 41, 9546-9553. [CrossRef]

45. Han, Y.; Liu, Z.-H.; Yang, Z.; Wang, Z.; Tang, X.; Wang, T.; Fan, L.; Ooi, K. Preparation of $\mathrm{Ni}^{2+}-\mathrm{Fe}^{3+}$ Layered Double Hydroxide Material with High Crystallinity and Well-Defined Hexagonal Shapes. Chem. Mater. 2008, 20, 360-363. [CrossRef]

46. Miao, M.; Han, X.; Jia, R.; Ma, W.; Han, G. Synthesis and Electrocatalytic Properties of Ni-Fe-Layered Double Hydroxide Nanomaterials. In Energy Technology; Wang, T., Chen, X., Guillen, D.P., Zhang, L., Sun, Z., Wang, C., Haque, N., Howarter, J.A., Neelameggham, N.R., Ikhmayies, S., et al., Eds.; Springer International Publishing: Cham, Switzerland, 2019 ; pp. $293-301$.

47. El-Reesh, G.Y.A.; Farghali, A.A.; Taha, M.; Mahmoud, R.K. Novel synthesis of Ni/Fe layered double hydroxides using urea and glycerol and their enhanced adsorption behavior for Cr(VI) removal. Sci. Rep. 2020, 10, 1-20. [CrossRef]

48. Abdelwahab, A.; Castelo-Quibén, J.; Pérez-Cadenas, M.; Maldonado-Hódar, F.J.; Carrasco-Marín, F.; Pérez-Cadenas, A.F. Insight of the effect of graphitic cluster in the performance of carbon aerogels doped with nickel as electrodes for supercapacitors. Carbon 2018, 139, 888-895. [CrossRef]

49. Castelo-Quibén, J.; Abdelwahab, A.; Pérez-Cadenas, M.; Morales-Torres, S.; Hódar, F.J.M.; Carrasco-Marín, F.; Pérez-Cadenas, A.F. Carbon-Iron electro-catalysts for $\mathrm{CO}_{2}$ reduction. The role of the iron particle size. J. $\mathrm{CO}_{2}$ Util. 2018, 24, 240-249. [CrossRef]

50. Rennie, A.J.R.; Martins, V.L.; Smith, R.; Hall, P.J. Influence of Particle Size Distribution on the Performance of Ionic Liquid-based Electrochemical Double Layer Capacitors. Sci. Rep. 2016, 6, 22062. [CrossRef] [PubMed]

51. Yang, H.; Guo, T.; Yin, D.; Liu, Q.; Zhang, X.; Zhang, X. A high-efficiency noble metal-free electrocatalyst of cobalt-iron layer double hydroxides nanorods coupled with graphene oxides grown on a nickel foam towards methanol electrooxidation. J. Taiwan Inst. Chem. Eng. 2020, 112, 212-221. [CrossRef]

52. Li, P.; Du, C.; Gao, X.; Zhuang, Z.; Xiang, D.; Zhang, C.; Chen, W. Insights into the morphology and composition effects of one-dimensional CuPt nanostructures on the electrocatalytic activities and methanol oxidation mechanism by in situ FTIR. Nanoscale 2020, 12, 13688-13696. [CrossRef]

53. Ma, K.; Cheng, J.; Liu, F.; Zhang, X. Co-Fe layered double hydroxides nanosheets vertically grown on carbon fiber cloth for electrochemical capacitors. J. Alloy. Compd. 2016, 679, 277-284. [CrossRef]

54. Wang, F.; Wang, T.; Sun, S.; Xu, Y.; Yu, R.; Li, H. One-step synthesis of Nickle Iron-layered double hydroxide/reduced graphene oxide/carbon nanofibres composite as electrode materials for asymmetric supercapacitor. Sci. Rep. 2018, 8, 8908. [CrossRef]

55. Zaher, A.; Taha, M.; Farghali, A.A.; Mahmoud, R.K. Zn/Fe LDH as a clay-like adsorbent for the removal of oxytetracycline from water: Combining experimental results and molecular simulations to understand the removal mechanism. Environ. Sci. Pollut. Res. 2020, 27, 12256-12269. [CrossRef]

56. Zhang, X.; Ikram, M.; Liu, Z.; Teng, L.; Xue, J.; Wang, D.; Li, L.; Shi, K. Expanded graphite/NiAl layered double hydroxide nanowires for ultra-sensitive, ultra-low detection limits and selective NOx gas detection at room temperature. RSC Adv. 2019, 9, 8768-8777. [CrossRef]

57. Thommes, M.; Kaneko, K.; Neimark, A.V.; Olivier, J.P.; Rodriguez-Reinoso, F.; Rouquerol, J.; Sing, K.S.W. Physisorption of Gases, With Special Reference to the Evaluation of Surface Area and Pore Size Distribution (IUPAC Technical Report). Pure Appl. Chem. 2015, 87, 1051. [CrossRef]

58. Kruk, M.; Jaroniec, M. Gas Adsorption Characterization of Ordered Organic-Inorganic Nanocomposite Materials. Chem. Mater. 2001, 13, 3169-3183. [CrossRef] 
59. Rajeshkhanna, G.; Rao, G.R. Micro and nano-architectures of $\mathrm{Co}_{3} \mathrm{O}_{4}$ on Ni foam for electro-oxidation of methanol. Int. J. Hydrog. Energy 2018, 43, 4706-4715. [CrossRef]

60. Zhou, X.-C.; Yang, X.-Y.; Fu, Z.-B.; Yang, Q.; Yang, X.; Tang, Y.-J.; Wang, C.-Y.; Yi, Y. Single-crystalline ultrathin nanofilms of Ni aerogel with $\mathrm{Ni}(\mathrm{OH})_{2}$ hybrid nanoparticles towards enhanced catalytic performance for ethanol electro-oxidation. Appl. Surf. Sci. 2019, 492, 756-764. [CrossRef]

61. Sennu, P.; Aravindan, V.; Lee, Y.-S. High energy asymmetric supercapacitor with $1 \mathrm{D} @ 2 \mathrm{D}$ structured $\mathrm{NiCo}_{2} \mathrm{O}_{4} @ \mathrm{Co}_{3} \mathrm{O}_{4}$ and jackfruit derived high surface area porous carbon. J. Power Sources 2016, 306, 248-257. [CrossRef]

62. Das, S.; Dutta, K.; Kundu, P.P.; Bhattacharya, S.K. Nanostructured Polyaniline: An Efficient Support Matrix for PlatinumRuthenium Anode Catalyst in Direct Methanol Fuel Cell. Fuel Cells 2018, 18, 369-378. [CrossRef]

63. Sheikh, A.; Abd-Alftah, K.E.-A.; Malfatti, C.F. On reviewing the catalyst materials for direct alcohol fuel cells (DAFCs). Energy 2014, 1, 1-10.

64. Huang, W.; Wang, H.; Zhou, J.; Wang, J.; Duchesne, P.N.; Muir, D.; Zhang, P.; Han, N.; Zhao, F.; Zeng, M.; et al. Highly active and durable methanol oxidation electrocatalyst based on the synergy of platinum-nickel hydroxide-graphene. Nat. Commun. 2015, 6 , 10035. [CrossRef]

65. Qian, L.; Luo, S.; Wu, L.; Hu, X.; Chen, W.; Wang, X. In situ growth of metal organic frameworks derived hierarchical hollow porous $\mathrm{Co}_{3} \mathrm{O}_{4} / \mathrm{NiCO}_{2} \mathrm{O}_{4}$ nanocomposites on nickel foam as self-supported flexible electrode for methanol electrocatalytic oxidation. Appl. Surf. Sci. 2020, 503, 144306. [CrossRef]

66. Habibi, B.; Ghaderi, S. Electrosynthesized Ni-Al Layered Double Hydroxide-Pt Nanoparticles as an Inorganic Nanocomposite and Potentate Anodic Material for Methanol Electrooxidation in Alkaline Media. Bull. Chem. React. Eng. Catal. 2017, 12, 1. [CrossRef]

67. Yang, H.; Geng, L.; Zhang, Y.; Chang, G.; Zhang, Z.; Liu, X.; Lei, M.; He, Y. Graphene-templated synthesis of palladium nanoplates as novel electrocatalyst for direct methanol fuel cell. Appl. Surf. Sci. 2019, 466, 385-392. [CrossRef]

68. Liu, H.; Song, C.; Zhang, L.; Zhang, J.; Wang, H.; Wilkinson, D.P. A review of anode catalysis in the direct methanol fuel cell. J. Power Sources 2006, 155, 95-110. [CrossRef] 